\title{
AN UNPREDICTED ANCIENT COLONIZATION OF THE WEST INDIES BY NORTH AMERICAN RODENTS: DENTAL EVIDENCE OF A GEOMORPH FROM THE EARLY OLIGOCENE OF PUERTO RICO
}

by LAURENT MARIVAUX ${ }^{1, *}$, JORGE VÉLEZ-JUARBE ${ }^{2}$, LÁZARO W. VIÑOLA LÓPEZ $^{3}$, PIERRE-HENRI FABRE ${ }^{1,4}$, FRANÇOIS PUJOS ${ }^{5}$, HERNÁN SANTOSMERCADO $^{6}$, EDUARDO J. CRUZ ${ }^{6}$, ALEXANDRA M. GRAJALES PÉREZ ${ }^{6}$, JAMES PADILLA $^{6}$, KEVIN I. VÉLEZ-ROSADO ${ }^{7}$, JEAN-JACQUES CORNÉE ${ }^{8,9}$, MÉLODY PHILIPPON $^{9}$, PHILIPPE MÜNCH ${ }^{8}$ and PIERRE-OLIVIER ANTOINE ${ }^{1, *}$

${ }^{1}$ Laboratoire de Paléontologie, Institut des Sciences de l'Évolution de Montpellier (ISE-M, UMR 5554, CNRS/UM/IRD/EPHE), c.c. 064, Université de Montpellier (UM), Place Eugène Bataillon, F-34095 Montpellier Cedex 05, France; e-mails: laurent.marivaux@umontpellier.fr, pierre-henri.fabre@umontpellier.fr, pierreolivier.antoine@umontpellier.fr

${ }^{2}$ Department of Mammalogy, Natural History Museum of Los Angeles County, 900 Exposition Boulevard, Los Angeles, CA 90007, USA; e-mail: jvelezjuar@nhm.org

${ }^{3}$ Florida Museum of Natural History, University of Florida, Gainesville, FL 32611-7800, USA; e-mail: lwv194@gmail.com

${ }^{4}$ Mammal Section, Life Sciences, Vertebrate Division, The Natural History Museum, Cromwell Rd, South Kensington, London SW7 5BD, UK

${ }^{5}$ Instituto Argentino de Nivología, Glaciología y Ciencias Ambientales (IANIGLA), CCT-CONICET-Mendoza, Avda. Ruiz Leal s/n, Parque Gral. San Martín, 5500 Mendoza, Argentina; e-mail: fpujos@mendozaconicet.gob.ar

${ }^{6}$ Department of Geology, University of Puerto Rico, Mayagüez Campus, PO Box 9017, Mayagüez, Puerto Rico 00681, USA; e-mails: hernan.santos@upr.edu, eduardo.cruz1@upr.edu, alexandra.grajales@upr.edu, james.padilla@upr.edu 
${ }^{7}$ Museum of Paleontology and Department of Earth and Environmental Sciences, University of Michigan, 1109 Geddes Ave., Ann Arbor, MI 48109, USA; e-mail: kvelez@umich.edu

${ }^{8}$ Géosciences Montpellier (UMR 5243, CNRS/UM/Université des Antilles), c.c. 060, Université de Montpellier (UM), Place Eugène Bataillon, F-34095 Montpellier Cedex 05, France; e-mails: jeanjacques.cornee@umontpellier.fr, philippe.munch@umontpellier.fr

${ }^{9}$ Géosciences Montpellier (UMR 5243, Université des Antilles/CNRS/UM), Université des Antilles, Campus de Fouillole, F-97159 Pointe-à-Pitre Cedex, Guadeloupe, France (French West Indies); e-mail: melody.philippon@univ-antilles.fr

*Corresponding authors

Laurent Marivaux, ORCID identifier: https://orcid.org/0000-0002-2882-0874

Pierre-Olivier Antoine, ORCID identifier: https://orcid.org/0000-0001-9122-1818 


\begin{abstract}
West Indies are a natural laboratory for the study of biogeography and evolution, especially for mammals. The modalities of their arrival in the Caribbean islands are highly controversial issues, and palaeontological evidence remains particularly elusive. Lower Oligocene deposits of Puerto Rico (c. $29.5 \mathrm{Ma}$ ) have recently yielded the oldest archipelago rodents, with teeth of two chinchilloid caviomorphs of South American origin. Here we report the discovery of additional dental remains from the same level, testifying to the occurrence of another rodent group. Their morphology is singular but otherwise characteristic of North/Central American geomyin geomorphs (including extant kangaroo rats, pocket mice, and pocket gophers), and leads us to propose here a new taxon: Caribeomys merzeraudi gen. et sp. nov. The evidence of geomorphs in the West Indies challenges the view that all extinct and extant Antillean rodents derived from South American sources. The morphological singularity of this Puerto Rican geomorph also suggests an early split of this insular lineage from coeval mainland counterparts, and its dispersal towards the West Indies sometime around the Eocene-Oligocene transition. This unexpected rodent adds to the few cases of Antillean terrestrial vertebrates of North American origins, such as solenodonotan eulipotyphlans. In the absence of subaerial land connections between both landmasses, an overwater dispersal may explain mid-Palaeogene colonization of the West Indies by geomorph rodents.
\end{abstract}

Key words: Caribbean islands, Rodentia, Geomorpha, Palaeogene, palaeobiogeography. 
RODENTS are one of the most speciose land mammal components of the Caribbean islands (e.g. Wilson \& Reeder 2005). Regardless of the many species introduced by humans (e.g. Cooper 2008; MacPhee 2009), hutias (Capromyinae, Echimyidae, Octodontoidea, Caviomorpha) and rice-rats (Oryzomyini, Sigmodontinae, Cricetidae, Muroidea) were once the most diverse West Indian rodent groups, although representing only part of the past rodent diversity on these islands. All rice-rats and several species of hutias have recently become extinct (e.g. MacPhee 2009; Brace et al. 2015; Cooke et al. 2017; Turvey et al. 2017; Upham \& Borroto-Páez 2017), but so have other endemic caviomorph hystricognaths, such as the heteropsomyine echimyids and the iconic "giant hutias" of chinchilloid affinities (see Marivaux et al. 2020). Their phylogenetic origins, historical biogeography and the causes of their extirpation, have long been debated issues. Comparative anatomy studies and phylogenies derived from available morphological and molecular data have shown that all extinct and extant rodent groups endemic to the Greater and Lesser Antilles, evolved from South American sources (e.g. MacPhee \& Iturralde-Vinent 1995, 2005; Woods et al. 2001; MacPhee 2005; Fabre et al. 2014, 2017; Brace et al. 2015; Courcelle et al. 2019; Marivaux et al. 2020). Recent palaeontological evidence (Marivaux et al. 2020) and molecular divergence estimates (Fabre et al. 2014; Brace et al. 2015; Courcelle et al. 2019) have further revealed that the arrival of rodents on the West Indian archipelago likely occurred through multiple and time-staggered dispersal events (chinchilloids then subsequently echimyid octodontoids [+ caviid, but in southern Lesser Antilles only; MacPhee et al. 2000] among caviomorphs, and lastly oryzomyin muroids). Although the timing of these dispersals is now relatively better bracketed, the modalities (land connection versus overwater transport) and pathways of these dispersals remain hypothetical and disputed (e.g. Hedges et al. 1992; MacPhee \& IturraldeVinent 1995, 2005; Hedges 2001, 2006; Dávalos 2004; Ali 2012). The palaeobiogeographical scenarios for land-mammals derive from limited palaeontological data and phylogenetic inferences (either based on morphology or on genes/proteins of living and recently extinct species), but also from partial and varying geological and tectonic models, especially regarding emerged landmasses (e.g. Pindell \& Barrett 1990; MacPhee \& Iturralde-Vinent 1995, 2005; Hedges 1996; Iturralde-Vinent \& MacPhee 1999; Woods et al. 2001; Graham 2003; Roca et al. 2004; MacPhee 2005; Iturralde-Vinent 2006; Fabre et al. 2014; Brace et al. 2015, 2016; Courcelle et al. 2019; Delsuc et al. 2019; Presslee et al. 2019; Marivaux et al. 2020). The same is true of scenarios for the origins of many other terrestrial organisms on the Caribbean islands (e.g. Heinicke et al. 2007; Alonso et al. 2012; Matos-Maraví et al. 2014; Dziki et al. 2015; Chamberland et al. 2018; Čandek et al. 2019; Tong et al. 2019; Blackburn 
et al. 2020; Crews \& Esposito 2020). The current diversity of West Indian mammals is so eroded, and the fossil record so incomplete, that the picture of their past-diversity can only be sketchy.

Here we report the discovery of dental remains of a new rodent from the early Oligocene of Puerto Rico (c. $29.5 \mathrm{Ma}$; San Sebastian Formation). The fossils were collected in 20192020 in the residues of fine wet-screenings $(1 \mathrm{~mm} \leq$ grains $<2 \mathrm{~mm})$ of sediments from the LACM Loc. 8060 fossil-bearing layer (Río Guatemala, San Sebastián; Fig. 1). In 2019, excavations of the same layer and coarse wet-screenings $(>2 \mathrm{~mm})$ of the extracted sediments had already led to the discovery of dental remains of two chinchilloid caviomorph rodents (Marivaux et al. 2020), representing the earliest direct evidence of colonization of the Greater Antilles by South American rodents (Vélez-Juarbe et al. 2014). We describe here two isolated molariform teeth documenting a small rodent species, whose characteristics differ from those of any known muroids or South American caviomorphs, extinct and extant, but rather match those of some Palaeogene rodents recorded in North and Central America, known as Geomorpha (e.g. Flynn et al. 2008). This material is admittedly limited, but the morphology of these teeth leads us to propose here a new taxon: Caribeomys merzeraudi gen. et sp. nov. We analyse and compare this new rodent, and discuss the macroevolutionary and palaeobiogeographical implications of this ancient unexpected rodent colonization from North America to the Greater Antilles.

\section{MATERIAL AND METHODS}

Fossil recovery and extraction. The LACM Loc. 8060 fossil-bearing locality is a $15-20 \mathrm{~cm}$ thick layer of silty claystone (Vélez-Juarbe et al. 2007, 2014; Vélez-Juarbe \& Domning, 2014; Marivaux et al. 2020). We excavated and collected c. $400 \mathrm{~kg}$ of sediments along this layer (Fig. 1). When fully dry, the gross sediments were treated by wet screening (two meshes of sieves; $2 \mathrm{~mm}$ and $1 \mathrm{~mm}$ ) directly in the water of the Río Guatemala. The coarse residues of screening ( $\geq 2 \mathrm{~mm}$ ) were carefully scrutinized by naked eyes in situ (on the riverbank), in order to collect the medium-sized fossil elements. The fine residues $(1 \mathrm{~mm} \leq$ grains $<2 \mathrm{~mm})$ were generally screen/washed twice, dried, and observed under stereomicroscopes in our field laboratory, and afterwards. The fossil material consists primarily of isolated teeth, among which the two specimens of rodents reported here. 
Fossil repository. The fossil specimens described in this paper are permanently stored in the palaeontological collections of the Natural History Museum of Los Angeles County (LACM), Los Angeles, USA.

Dental loci, nomenclature and measurements. The dental terminology employed here (Fig. 2) is updated and modified after Wahlert (1983), Korth (1994, 2007), Marivaux et al. (2004), Calede \& Glusman (2017), and Calede \& Rasmussen (2020). Teeth were measured (maximum mesiodistal length and maximum buccolingual width) with a microscope fitted with a calibrated reticle (Measuroscope Nikon 10).

High-resolution $\mu C T$-scan. We used X-ray microtomography ( $\mu \mathrm{CT}$-scan) to obtain threedimentional digital models (3D renderings) of the fossils (Figs 2-4). The specimens were scanned with a resolution of $5 \mu \mathrm{m}$ (LACM 162478) or $4.5 \mu \mathrm{m}$ (LACM 162449), using a $\mu$ CTscanning station EasyTom 150 / Rx Solutions (Montpellier RIO Imaging, ISE-M, Montpellier, France). The crown and roots of each tooth were virtually delimited by manual segmentation under AVIZO 7.1 software (Visualization Sciences Group). The teeth were prepared within a "Label Field" module of AVIZO, using the segmentation threshold selection tool. The renderings of the 3D digital models of the teeth described in this paper (Marivaux et al. 2021) are available on the MorphoMuseuM website (http://morphomuseum.com), an online open access platform that aims at enhancing accessibility to $3 \mathrm{D}$ models.

Optical photography. Some of the tooth pictures (Figs 3A, 4A) are photographs of original specimens, whitened using magnesium smoke. These views are the result of the fusion of multifocus images obtained with an optical stereomicroscope (Leica M 205C) connected to a camera (Leica DFC 420C).

Institutional abbreviations. Amherst, Amherst Museum; F:AM, Frick American Mammals, the American Museum of Natural History; LACM, Natural History Museum of Los Angeles County, Los Angeles; MCZ, Museum of Comparative Zoology, Harvard; UMPE, Universidad del Mar, campus Puerto Escondido; UNSM, University of Nebraska, State Museum, Lincoln; SDSM, Museum of Geology, South Dakota School of Mines and Technology, Rapid City. 


\section{SYSTEMATIC PALAEONTOLOGY}

We follow here the systematics of Geomorpha proposed by Flynn et al. (2008).

Class MAMMALIA Linnaeus, 1758

Order RODENTIA Bowdich, 1821

Suborder ISCHYROMYIFORMES Marivaux, Vianey-Liaud \& Jaeger, 2004

Infraorder GEOMORPHA Thaler, 1966

Parvorder GEOMYINA Bonaparte, 1845

Family indeterminate

Genus CARIBEOMYS nov.

LSID. urn:Isid:zoobank.org:act:E55A5360-1CCB-42BD-A372-D858DA588600

Type species. Caribeomys merzeraudi sp. nov.

Etymology. The name derives from the Spanish "Caribe" (El Caribe) corresponding to the Caribbean region (Caribbean Sea and West Indies), with the Greek suffix $\mu \nu \varsigma$ (mys), mouse.

Diagnosis. As that of the type and only species.

Geographic distribution and stratigraphic range. Puerto Rico (West Indies), late early Oligocene.

Caribeomys merzeraudi sp. nov.

Figures 3-4

LSID. urn:1sid:zoobank.org:act:4C7AE962-BB9F-47A4-B5A1-39D6490EB416 
Etymology. The species name pays tribute to our late colleague and friend, Gilles Merzeraud (1965-2020), who established the stratigraphical section of Río Guatemala from which the fossils described here originate.

Holotype. LACM 162449, right lower molar (m1 or m2; Figs 2A, 4A-P).

Hypodigm. In addition to the holotype, LACM 162478, a right fourth lower deciduous premolar (dp4; Figs 2B, 3A-N).

Horizon and locality. Late early Oligocene (c. 29.5 Ma) San Sebastian Formation at locality LACM Loc. 8060, on the west bank of Río Guatemala, San Sebastián, Puerto Rico (VélezJuarbe et al. 2007, 2014; Vélez-Juarbe \& Domning, 2014; Ortega-Ariza et al. 2015; Marivaux et al. 2020).

Diagnosis (based on the two dental specimens available). Small geomyin species (c.100 g) with mesodont teeth displaying an unusually thick enamel layer. Differs from other Geomyina (i.e. Heliscomyidae, Florentiamyidae, Geomyoidea incertae sedis, Heteromyidae and Geomyidae) in having lower teeth with the buccal protostylid and hypostylid linked to the protoconid (or metalophid) and hypoconid (or hypolophid), respectively. Differs from Heliscomyidae (most species of Heliscomys) in having teeth much less brachydont and bunodont, without well-differentiated main cuspids and buccal stylids. Differs from Florentiamyidae (e.g. Kirkomys, Florentiamys), some species of Heteromyidae (e.g. Eochaeotodipus, Perognathus) and all Geomyidae in having well-defined and buccolinguallyextended anterocingulid and posterocingulid. Differs from some other low-crowned heteromyids (such as Proheteromys) and some stem geomyoids (e.g. Proharrymys) in having lingual and buccal cuspids which, when merged (with wear), form transverse metalophid and hypolophid, not V-shaped lophids. Differs from most geomyids and high-crowned heteromyids in having teeth much more low-crowed and mesodont (not hypsodont or hypselodont).

Body-mass estimate of $c .100 \mathrm{~g}$ is based on the LACM 162449 molar area, calculated from the least-squares regression equation of Legendre (1986). 
Description

The two specimens are right lower teeth, LACM 162478 representing a pristine fourth deciduous premolar (dp4; Fig. 3A-N), and LACM 162449 a worn first or second molar (m1 or m2; Fig. 4A-P). The premolar is half the size of the molar, low-crowned, and its occlusal surface lacks any mark of abrasion and attrition wear, thereby indicating it is a dental germ that belonged to a new-born individual. In contrast, given its advanced stage of wear (abrasion related to mastication), the LACM 162449 molar belonged to an old adult individual. Both teeth display a noticeably thick enamel layer (Figs 3B-D, 4A-D), which has certainly contributed to their preservation (without distortion) during fossilization. The roots are lacking on both specimens, and crowns are preserved from the cervix. The basalmost part of the crown of LACM 162478, where roots should have started, displays small but well-marked mesial and distal outward folds (Fig. 3G, K), thereby indicating that two roots were present and anchored in the dentary with diverging directions on a mesiodistal axis. Such a root configuration strengthens support for the deciduous status of LACM 162478, as this orientation of the roots is usual for the unique lower deciduous premolar in rodents. The dentine is only partially preserved and highly fractured on the molar (Fig. 4I), whereas it has entirely vanished on the deciduous premolar, the crown of the latter consisting only of a hollow enamel cap (Fig. 3F).

LACM $162478 d p 4$. In occlusal view, this tooth is longer than it is wide (mesiodistal length: $1.51 \mathrm{~mm}$, buccolingual width: $1.26 \mathrm{~mm}$ ), having an overall rectangular shape but with rounded edges and corners (Fig. 3A, E, K, I, M). The trigonid region is only slightly narrower than the talonid region, making the occlusal outline of this tooth almost ovoid, with a mesiodistal long axis. Being pristine, this deciduous premolar reveals its low crown elevation (mesodonty; Fig. 3H, L), and its occlusal relief returns a somewhat singular structural pattern. Four main cuspids can be identified, but only the mesialmost one, i.e. the metaconid, is well defined (Fig. 3A, E, G, I, M). The protoconid, hypoconid and entoconid appear more like discreet enamel swellings, subsumed within transverse cristids and accessory enamel wrinkles. The metaconid is protruding and mesiolingually canted, and is located slightly more buccal than the entoconid on a mesiodistal axis. The entoconid seems mesiodistally extended and buccolingually compressed due to the development of short anterior and posterior arms (Fig. 3A, E, G, K). The protoconid and hypoconid are mesiodistally aligned. The lingual 
cuspids (metaconid and entoconid) are marginally positioned, whereas the buccal ones (protoconid and hypoconid) are internal, lingually offset from the buccal margin. The entoconid and hypoconid are buccolingually aligned and linked by a thin but trenchant hypolophid, which is transverse in its lingual part and slightly buccomesially oriented before reaching the hypoconid. The protoconid is distally positioned with respect to the metaconid. A very short metalophid, notched in its middle, links the distobuccal flank of the metaconid to the lingual aspect of the protoconid (Fig. 3A, E, G, M). The buccal margin is bounded by a moderately elevated buccal cingulid that is interrupted at its midpoint by a V-shaped notch corresponding to the buccal opening of the hypoflexid (Fig. 3G-H). This buccal cingulid bears well-defined and strong protostylid and hypostylid, which are located directly buccal to the protoconid and the hypoconid, respectively. An accessory stylid also occurs distal to the protostylid. The hypostylid and hypoconid are linked together by a very short and buccolingually oriented cristulid. A similar cristulid is also present between the protostylid and the protoconid. The buccal cingulid is prolonged mesiolingually by a low, short but wellmarked and arcuate anterocingulid, and distally by a low but well-defined, long and slightly circular posterocingulid. The anterocingulid connects the protostylid to the buccal base of the metaconid, and together with the protoconid, metalophid and metaconid isolate a small, narrow and crescent-shaped anterofossettid (Fig. 3A, E, M). The posterocingulid extends from the distobuccal aspect of the hypostylid, around the distobuccal corner of the tooth, and along the distal margin of the tooth for its entire width, ultimately connecting to the posterior arm of the entoconid. There is no trace of hypoconulid on the posterocingulid. The hypolophid and posterocingulid (clearly lower) delimit a narrow and buccolingually extended metafossettid, which appears as a distal gutter at the base of the gently sloping distal flanks of the hypoconid and hypolophid (Fig. 3A, E, G, J-K). Mesiolingually, the metaconid displays a long but low and arcuate posterior arm, which runs distally to reach a small and mesiodistally elongated mesostylid (Fig. 3E, G, K-L). The latter remains separated distally from the anterior arm of the entoconid, due to the presence of a wide V-shaped notch that punctuates the lingual crown margin, thereby maintaining the mesoflexid open lingually (Fig. 3K-L). There is no development of ectolophid in the centre of the talonid basin, so the mesoflexid is confluent with the hypoflexid, thus generating a central transverse furrow-like valley, open lingually and buccally (Fig. 3G-H, K-L). On either side of this transverse valley that bisects the tooth, irregularities on the enamel surface, appearing as roughnesses (or wrinkles), are present along the internal sloping flanks of the cuspids and cristids/lophids. 
LACM $162449 \mathrm{~m} 1$ or $\mathrm{m} 2$. This lower molar is markedly larger than dp4 and subrectangular in occlusal outline (with rounded corners; Fig. 4A, E-F), being slightly wider than it is long (mesiodistal length: $1.98 \mathrm{~mm}$, buccolingual width: $2.07 \mathrm{~mm}$ ). Its occlusal surface is flat (Fig. $4 \mathrm{~K}-\mathrm{P})$ due to an advanced stage of wear, which somewhat obscures the delineation of the main structures. The tooth exhibits a bilobed pattern with a narrow, deep and transverse central valley, and it is bounded mesially and distally by an anterocingulid and a posterocingulid, respectively (Fig. 4E-F, G, J). The two main transverse lophids are very wide, each displaying an enamel layer remarkably thick (either on their trailing edge or on their leading edge) as well as a narrow central dentine layer (Fig. 4A, D, E-F). The anterocingulid and posterocingulid are slightly affected by attritional wear (both cingulids being at the same occlusal level as that of the two main lophids, which are strongly abraded). Thus, considering the marked thickness of the transverse dentine layer that appears upon each lophid due to wear, it may be expected that the tooth, when pristine, was much more highcrowned, perhaps twice the height of the currently worn crown (Fig. 4G-H, K-L, N, P). The cuspids/stylids are not clearly defined, as they are subsumed within the lophids, a condition which was likely achieved at an early stage of wear due to the strong thickness of the enamel layer. Despite the wear, the overall dental pattern of this molar (i.e. two internal lophids, peripheral cingulids, and a deep and transverse central valley bisecting the crown), is however basically similar to that of the LACM 162478 deciduous premolar (Fig. 3A-N). The bilophate pattern of LACM 162449 likely derives from the buccolingual coalescences of the bulbous and mesiodistally compressed lingual cuspids with the similarly bulbous and mesiodistally compressed buccal cuspids and stylids. Based on the pattern of the LACM $162478 \mathrm{dp} 4$, on the LACM $162449 \mathrm{~m} 1$ or $\mathrm{m} 2$, the distal main lophid is recognized here as a hypolophid, which consists of a merged entoconid and hypoconid, plus a hypostylid that likely occupied a slightly more mesial position on the buccal cingulid. Likewise, the mesial main lophid is recognized as a metalophid, resulting from the fusion of the metaconid with the protoconid and a protostylid situated on the mesial part of the buccal cingulid. These two lophids show in their middle part some kind of mesiodistal pinching points, which could testify, to some extent, to the delineation of the regions of these main bulbous cuspids (Fig. 4A, E-F, J). The anterocingulid stretches from the mesiolingual aspect of the metaconid to the anterobuccal corner of the tooth, the latter being assimilated to the mesial part of the buccal cingulid on which the protostylid of the metalophid would be included. Similarly, the posterocingulid 
extends from the posterior arm of the entoconid, along the posterior margin of the tooth for its entire width, and around the distobuccal corner of the tooth, the latter being assimilated to the distal part of the buccal cingulid on which the hypostylid of the hypolophid would be included. The anterocingulid and posterocingulid are very closely positioned to the metalophid and hypolophid, respectively, but remain distinct from these two main lophids by the presence of very narrow and shallow transverse grooves (faintly visible), corresponding to the anterofossettid and metafossettid, respectively (Fig. 4A, E-F, G, J, M). The buccal and lingual margins of the crown are notched in their middle. These openings correspond to the extension of the central transverse and narrow valley that separates the two main lophids. This central valley is very deep with almost vertical sides (Fig. 4A, E-F, J), and corresponds to the confluence of a narrow hypoflexid with a similarly narrow mesoflexid.

\section{Comparisons and discussion}

The two specimens discovered represent two lower dental loci, documenting distinct ontogenetic stages, and testifying to the co-occurrence of both a new-born and an adult individual at LACM Loc. 8060. Despite such disparate morphological information, these two cheek teeth have a comparable overall Bauplan. The two teeth have a similar thickness of the crown enamel layer (i.e. very thick; Figs 3C-D, 4C-D), and their occlusal pattern is basically bilophodont, with a deep and transverse central valley bisecting the occlusal crown surface into two distinct main lophids, associated with peripheral cingulids (Figs 3, 4). These two dental specimens are further compatible in size and morphology, and are thus considered here as documenting a single rodent species. Understanding the occlusal morphology of the pristine deciduous premolar (dp4) was essential to decipher the structural pattern of the worn molar, especially to recognize plausibly homologous structures. Although autapomorphous in many features (see below), the occlusal pattern of these two lower teeth is distinguished primarily by the lingual and buccal cuspids plus unusual buccal stylar cuspids that are arranged in two well-separated transverse rows. Such a pattern of lower teeth characterized by the addition of stylids to lophids is autapomorphic for Geomyina among geomorph rodents (e.g. Wahlert 1983; Korth et al. 1991; Korth 1994; 2007; Flynn et al. 2008). This is particularly shown in lower teeth of North American Palaeogene geomyins (Fig. 5), such as heliscomyids (e.g. Heliscomys Cope, 1873), florentiamyids (e.g. Florentiamys Wood, 1936, 
Kirkomys Wahlert, 1984), stem geomyoids (i.e. Geomyoidea incertae sedis sensu Flynn et al. 2008; e.g. Proharrymys Korth \& Branciforte, 2007, Mojavemys Lindsay, 1972), heteromyids (e.g. Proheteromys Wood, 1932, Eochaeotodipus Korth, 2008), and geomyids (e.g. Pleurolicus Cope, 1878, Gregorymys Wood, 1936), in which teeth are widened buccally by the addition of well-defined protostylid and hypostylid, positioned directly buccal to the protoconid and hypoconid, respectively. Analogous widenings also occur lingually on their upper teeth, by the addition of a prominent lingual cingulum bearing moderately to strongly developed styles. With abrasion and attrition wear, upper and lower teeth of Geomyina are well recognizable by their typical bilophate/bilobed pattern. The new West Indian taxon, Caribeomys, is here considered as being related to a Geomyina among Geomorpha due to its bilophodonty including buccal stylids in lophids. This condition does not match that of stem Geomorpha (Geomorpha incertae sedis sensu Flynn et al. 2008), such as representatives of the Oligocene-Miocene Jimomyidae (Jimomys Wahlert, 1976, Texomys Slaughter, 1981, and Zetamys Martin, 1974), or the Eocene Griphomys Wilson, 1940, Meliakrouniomys Harris \& Wood, 1969, and Floresomys Fries et al., 1955, the geomorph status of which is questioned (see Flynn et al. 2008). Due to wear, the occlusal pattern of the lower molar of Caribeomys might, at first glance, be very close to that of lower molars of Meliakrouniomys (deep, narrow and buccolingually open transverse valley bisecting the tooth; short and very low anterocingulid and posterocingulid, closely spaced from, respectively, the thick transverse metalophid and hypolophid). However, the LACM 162449 molar displays a better defined posterocingulid, without hypoconulid, and a narrower transverse valley. The LACM 162478 premolar also displays a long and clearly better-defined posterocingulid, and above all it develops buccal stylids, which are absent in Meliakrouniomys. Lower teeth of Caribeomys differ from those of Griphomys in being slightly higher-crowned, in lacking the mesoconid, and in bearing a strong and complete hypolophid (absent in Griphomys). The dental pattern of Jimomys is only superficially reminiscent to that of Caribeomys. Indeed, at first sight, lower molars of Jimomys exhibit a bilobed pattern (with wear), but this is a "false" bilophodonty. The anterocingulid and posterocingulid of lower molars of Jimomys are not low, but particularly well developed (i.e. strong and elevated), and as such described as anterolophid and posterolophid, respectively. Despite the presence of a deep central transverse valley bisecting the crown mesiodistally in two separated lobes, as observed in Caribeomys, the bilobed dental pattern characterizing lower molars of Jimomys, derives from a tetralophodont pattern. Compared with Caribeomys, lower molars of Jimomys are higher-crowned, they do not show any development of buccal stylids, and the deciduous and permanent premolars are 
pentalophodont, characterized by the addition of a strong central lophid (i.e. a mesolophid), in contrast to the condition seen in the LACM 162478 dp4 attributed to Caribeomys.

The diagnostic characters of the different families of Geomyina so far recognized are primarily cranial features (notably for differentiating early representatives among extinct heliscomyids and florentiamyids, and extant heteromyids and geomyids), although dental characteristics are also mentioned (e.g. Wahlert 1983, 1985, 1991; Korth et al. 1991; Korth 1994, 2008; Flynn et al. 2008; Jiménez-Hidalgo et al. 2018; Calede \& Rasmussen 2020). With only two isolated lower teeth documenting this Oligocene rodent from Puerto Rico, despite their apparent geomyin affinities, the question remains as to whether this new taxon, Caribeomys, could belong to one of the defined families, or constitute a distinct basal branch within the parvorder. In all Palaeogene taxa of Geomyina (Fig. 5), the buccal stylar cuspids (protostylid and hypostylid) are clearly much smaller than the four main bulbous cuspids, and remain separated from the protoconid or metalophid (i.e. when protoconid and metaconid are merged) and the hypoconid or hypolophid (i.e. when hypoconid and entoconid are merged). It is only at some advanced stage of wear that these two stylids incorporate the metalophid and the hypolophid. On the pristine LACM $162478 \mathrm{dp} 4$ attributed to Caribeomys, the main cuspids are moderately bulbous, even appearing as discreet tubercles within the two main lophids. Because of this quite weak development of the main cuspids, the buccal stylids may in contrast appear well marked and salient, but they still remain lower than the buccal main cuspids. In Caribeomys, one of the differences from other geomyin taxa is the connection of the protostylid and hypostylid with the protoconid and hypoconid, respectively (Figs 3, 5B). In this taxon, the buccal stylids are therefore incorporated in the lophids, not due to an advanced wear, but due to the presence of thin and very short cristulids. The LACM 162449 $\mathrm{m} 1$ or $\mathrm{m} 2$ attributed to Caribeomys is particularly worn, and the protostylid and hypostylid are undifferentiated in the buccal region of the metalophid and hypolophid, respectively (Figs 4, 5A). The same is true for the four main cuspids, which are merged together without clear remnant of delineations, and entirely subsumed within these two main and massive lophids. LACM 162449 is noticeably worn, but clearly not at a very advanced stage of wear given the still high elevation of the mesial and distal walls of the deep central and transverse valley separating the two main lophids and bisecting the tooth (Fig. 4). On this molar, the lack of delineation of the main linked structures forming the two massive lophids is a consequence of the great thickness of the enamel layer, a condition that is somewhat unusual, if not unique among the earliest geomyin rodents (a thick enamel layer is observed in some more recent 
geomyoid taxa, such as for instance Mojavemys Lindsay, 1972, Phelosaccomys Korth \& Reynolds, 1994, or Schizodontomys Rensberger, 1973). In early Geomyina, the absence of delineation of the main bulbous cusp(-id)s and absorption of stylar cusp(-id)s in the loph(-id)s are observed only in old individuals with extreme abrasion and attrition wear of low-crowned cheek teeth (in heliscomyids, florentiamyids, and in some heteromyids), or in young individuals of more advanced and younger taxa that have moderately to very high-crowned teeth (other heteromyids and geomyids).

The two teeth documenting Caribeomys are also characterized by the presence of welldefined and buccolingually extended anterocingulid and posterocingulid, as mesiolingual and distolingual extensions of the buccal cingulid bearing the stylids. The presence of still welldeveloped antero- and postero- cingulids is primarily observed in heliscomyids (most species of Heliscomys; Fig. 5C-E; e.g. Korth et al. 1991; Korth 1994, 2008a; Korth \& Branciforte 2007; Kelly 2009) and, to some extent, in some low-crowned species of stem geomyoids (e.g. Proharrymys; Korth \& Branciforte 2007; Fig. 5L) and heteromyids (such as Proheteromys; e.g. Korth 2014; Korth \& Samuels 2015). However, Caribeomys differs from heliscomyids in having teeth much less brachydont (i.e. mesodont) but also much less bunodont, without welldifferentiated cuspids and stylids. It also differs from the aforementioned stem geomyoids and heteromyids in having lingual and buccal cuspids which, when merged (with wear), form transverse metalophid and hypolophid, not the V-shaped lophids (two chevrons) observed in Proheteromys and Proharrymys for instance (Fig. 5L). The presence of antero- and posterocingulids in lower teeth of Caribeomys also contrasts with lower teeth of florentiamyids (e.g. Kirkomys, Florentiamys; Fig. 5G-H, J) and some other species of heteromyids (e.g. Eochaeotodipus, Perognathus; Fig. 5K), in which these cingulids are faintly marked, buccolingually reduced to absent (e.g. Wahlert 1983; Korth 1994, 2008b; Korth \& Branciforte 2007). In the two latter families, when present, the anterocingulid is more frequently observed, but developed to varying degrees. Geomyids in general (geomyines and entoptychines; Fig. 5M-N) do not show any development of these two cingulids (in taxa with either low- or high-crowned teeth). With the retention of such cingulids, Caribeomys as well as heliscomyids and few heteromyids, exhibit therefore a primitive geomyin condition, which is found in stem Geomorpha (Geomorpha incertae sedis sensu Flynn et al. 2008) and characteristic of the Eomyidae, the extinct sister group of Geomorpha (e.g. Flynn 2008). However, in some Geomorpha incertae sedis, notably the Jimomyidae (see above; e.g. Jimomys, Texomys) and in Eomyidae (Eomyinae, Apeomyinae, and Yoderimyinae: e.g. 
Adjidaumo Hay 1899, Paradjidaumo Burke 1934, Apeomys Fahlbusch 1968, Apeomyoides Smith et al., 2006, Eomys Schlosser 1884, Yoderimys Wood 1955), the upper and lower tooth patterns were not as simplified as in Geomyina (i.e., bilophodonty), as their antero- and postero- cingulids turned into anterolophid and posterolophid, respectively, thereby generating "multilophodont" patterns (tetralophodonty or even pentalophodonty).

\section{DISCUSSION}

Despite a limited fossil material, this small early Oligocene Puerto Rican rodent exhibits dental attributes indicating undisputed basal geomyin geomorph affinities. However, it also displays a suite of startling specializations (e.g. very thick enamel layer, cuspids and stylids not well differentiated and interconnected) that makes this insular taxon new and distinct from known Palaeogene representatives of all recognized groups of Geomyina (i.e. Heliscomyidae, Florentiamyidae, Heteromyidae, Geomyidae, and Geomyoidea incertae sedis; see Flynn et al. 2008). The familial assignment of Caribeomys thus remains indeterminate to date as it requires further morphological support than current data allow. But considering its diagnostic autapomorphous dental traits compared with coeval stem geomyins, the possibility also exists that Caribeomys is the representative of a separate geomyin lineage (i.e. a distinct West Indian branch) having evolved in insular context. Regardless of the systematics issues, the presence of a rodent with North American affinities in lower Oligocene deposits of Puerto Rico also raises puzzling palaeobiogeographical questions. This discovery challenges the traditional view that all extinct and extant rodents endemic to the Greater and Lesser Antilles are proximately derived from South American sources (e.g. MacPhee \& Iturralde-Vinent 1995, 2005; Woods et al. 2001; MacPhee 2005; Fabre et al. 2014; Brace et al. 2015; Courcelle et al. 2019; Marivaux et al. 2020). The early Oligocene site at Río Guatemala in San Sebastián, northwestern Puerto Rico (LACM Loc. 8060), records two distinct rodent groups of radically different geographical origins: two chinchilloid caviomorphs of South American source (Marivaux et al. 2020), and a geomyin geomorph of North American source (Fig. 6). When and how did these rodents reach this Caribbean island, or more generally the Greater Antilles?

The Greater Antilles islands, including Cuba, Hispaniola and Puerto Rico (but not Jamaica), share geological histories dating back to the Cretaceous-Palaeogene Great Antillean 
arc system (Mann 2007; Pindell \& Kennan 2009; Stanek et al. 2009; Boschman et al. 2014). However, the island complex seemingly did not become permanently subaerial until the whole belt was tectonically deformed, i.e. not earlier than the late middle to late Eocene (e.g. Khudoley \& Meyerhoff 1971; Lewis et al. 1990; MacPhee \& Iturralde-Vinent 1995; IturraldeVinent \& MacPhee 1999; Graham 2003; Iturralde-Vinent 2006). The permanent land emersion certainly promoted survival of terrestrial animals that invaded the Greater Antilles from that time. It can be hypothesized that either land connections of South, Central (Chortis block) and North America with the Greater Antilles and/or overwater transports between these lands mediated these early rodent dispersals. Although an overwater dispersal from South America to the Greater Antilles cannot be ruled out, the GAARlandia hypothesis of a subaerial connection between both landmasses (via the emerged Aves Ridge; Fig. 6) during a sea level drop recorded around the Eocene-Oligocene transition (e.g. Miller et al. 2020), is often advocated to explain the origin of several terrestrial organisms (including the chinchilloid rodents) of South American sources on the Caribbean islands (e.g. MacPhee \& Iturralde-Vinent 1995, 2005; Iturralde-Vinent \& MacPhee 1999; MacPhee 2005; IturraldeVinent 2006; Alonso et al. 2012; Matos-Maraví et al. 2014; Dziki et al. 2015; Chamberland et al. 2018; Delsuc et al. 2019; Presslee et al. 2019; Tong et al. 2019; Blackburn et al. 2020; Crews \& Esposito 2020; Marivaux et al. 2020; Philippon et al. 2020). What about the Palaeogene dispersal of geomorph rodents from North America to the Greater Antilles? This relative sea level drop (e.g. Miller et al. 2020) might also have contributed to that dispersal in having generated a potential subaerial land bridge between southern North America (and/or Central America) and the Greater Antilles. There is so far no geological support for such a land connection at that time, but such a sea level drop might have contributed to shorten interisland distances, thus facilitating successful overwater dispersals for terrestrial organisms.

Jamaica, originally part of the Central American tectonic plate, has yielded a fossil rhinocerotoid of North American origin (Fig. 6) and the semi-terrestrial stem sirenian Pezosiren portelli in middle Eocene deposits (Domning et al. 1997; Domning 2001a), as well as iguanid and crocodyliform remains (Berg 1969; Domning \& Clark 1993; Pregill 1999; Vélez-Juarbe \& Brochu in press), thereby demonstrating the occupation of this Caribbean island by terrestrial taxa, during its partially subaerial and perhaps continuous connection with the mainland at that time (MacPhee et al. 1999). However, Jamaica subsequently remained partially or fully submerged until its re-emergence in the mid-Miocene, and may never have been directly connected to the Cainozoic Antillean arc (e.g. Buskirk 1985; Morgan 1993; 
Robinson 1994; MacPhee \& Iturralde-Vinent 1995; Iturralde-Vinent \& MacPhee 1999; Graham 2003; Iturralde-Vinent 2006; Pindell et al. 2009; Boschmann et al. 2014). Therefore, the overwater dispersal hypothesis (from mainland southern North America or from Jamaica) would better explain the pattern of colonization of the Greater Antilles (at least Puerto Rico) by North American stem geomorph rodents. Bracketing the age of that colonization remains difficult given the limited palaeontological data so far assembled, which does not allow establishing a time-calibrated phylogenetic context. Modern geomorph families (Geomyoidea: Geomyidae and Heteromyidae) diverged and adaptively radiated during the Oligocene and the early Miocene (e.g. Hafner 1993; Hafner et al. 2007; Montgelard et al. 2008; Meredith et al. 2011; Tapaltsyan et al. 2015; Jiménez-Hidalgo et al. 2018), while their extinct close relatives (Heliscomyidae, Florentiamyidae, and both stem Geomyoidea and few Geomyidae) are well represented as early as the late Eocene and early Oligocene in the fossil record of Central and North America (e.g. Korth 1994; Korth \& Eaton 2004; Flynn et al. 2008; Kelly 2009; Jiménez-Hidalgo et al. 2015, 2018; Ortiz-Caballero et al. 2020). The most likely ancestry of Geomorpha (as well as their sister groups Eomyidae and Castoroidea; e.g. Flynn 2008; Flynn and Jacob 2008) is expected from a middle Eocene North American sciuravid stock (e.g. Wood 1935; Wilson 1949; Wahlert 1985, 1991; Korth 1994; Marivaux et al. 2004; Flynn et al. 2008; Walton \& Porter 2008). The peculiar dental specialization characterizing Caribeomys with respect to its coeval North American stem geomyin counterparts may indicate that its lineage had diverged for some time. This would thus suggest that the dispersal of geomorphs towards the West Indies likely occurred well before rather than shortly before its appearance in the Puerto Rican fossil record, i.e. sometime during the late Eocene-earliest Oligocene interval.

Interestingly, this Puerto Rican geomorph rodent adds to the very few cases of Antillean terrestrial vertebrates of North American origins. The recent discovery of the plethodontid salamander Palaeoplethodon hispaniolae in ancient amber-bearing deposits (early-middle Miocene) of the Dominican Republic, represents a taxon of North and Central American affinities with no extant relatives in the region (Iturralde-Vinent \& MacPhee 1996; Poinar \& Wake 2015). The most famous example are the solenodonotans (Eulipotyphla), which are widely believed to have arrived in the Greater Antilles during the late Cretaceous, with a Palaeogene divergence of the two known West Indian families, the recently-extinct Nesophontidae and the extant Solenodontidae (Roca et al. 2004; Brace et al. 2016; Springer et al. 2018). The timing of solenodonotan colonization would be consistent with 
palaeogeographical reconstructions that place the proto-Greater Antilles close to North America (Iturralde-Vinent \& MacPhee 1999; Roca et al. 2004; Iturralde-Vinent 2006), in a period otherwise too early to explain the origin of the Antillean geomorph rodent. However, as the island complex of the Antillean arc system was not permanently subaerial before the late middle/late Eocene (e.g. Khudoley \& Meyerhoff 1971; Lewis et al. 1990; MacPhee \& Iturralde-Vinent 1995; Iturralde-Vinent \& MacPhee 1999; Graham 2003; Iturralde-Vinent 2006), then the possibility also exists that solenodonotans derive from a dispersal during the mid-Palaeogene of a now-extinct Palaeogene North American soricomorph relative (Asher et al. 2002; Roca et al. 2004; Brace et al. 2016; Sato et al. 2016). In that context, the solenodonotan ancestor may have had a biogeographical history similar to that of the Puerto Rican geomorph rodent. In the absence of clear subaerial land connections between southern North America and/or Central America with the Greater Antillean arc after the Palaeocene, overwater dispersals shall be advocated as a hypothesis for explaining such a colonization. By mid-Palaeogene times, the ancestors of the geomorph rodent and the plethodontid salamander - and possibly also the ancestor of solenodonotan eulipotyphlans - may have colonized the Greater Antilles, either through a single episode or a series of rafting episodes.

\section{CONCLUSIONS}

Without these two tiny teeth recovered from a single and limited spot in the Río Guatemala of Puerto Rico, it could not have been predicted that a stem geomorph of North American affinities was living in the Greater Antilles during the early Oligocene, alongside early chinchilloids of South American origins. Caribeomys is an ancient relative of modern North and Central American heteromyids (kangaroo rats and pocket mice) and geomyids (pocket gophers) and so far, it is the only evidence of the past presence of geomorphs in the West Indies. This rodent group is indeed absent from modern and Quaternary West Indian ecosystems, and it has never been reported in the rare Miocene records of the Greater Antilles or in the Eocene deposits of Jamaica (e.g. MacPhee et al. 2003; Blackburn et al. 2020). Morphological comparisons of Caribeomys with its Palaeogene North American counterparts indicate that this island lineage had diverged for some time, and likely dispersed toward the West Indies long before its appearance in the Puerto Rican fossil record (i.e. during the late Eocene-earliest Oligocene interval). What specifically were the modalities (overland versus 
overwater dispersal) and pathways for this rodent to reach Puerto Rico, or more generally the Greater Antilles? How long did this group survive in the Greater Antilles, at least in Puerto Rico? When did it become extinct? What caused its extinction? Geomorphs have flourished from the Oligocene to the present-day in North and Central America, but may only have been transitory in some Caribbean islands. Only fossil data will shed light on these issues. Early chinchilloids also documented in the Río Guatemala are possibly related to the PleistoceneHolocene West Indian "giant chinchilloid hutias" (see Marivaux et al. 2020). The latter were only recently extirpated from the West Indies (MacPhee 2009), where they possibly evolved in isolation for over 30 million years. Among solenodonotans, only Solenodontidae still live in the West Indies today, but they are endangered, occupying a relictual distribution in Cuba and Hispaniola (e.g. MacPhee 2009; Turvey \& Fritz 2011; Brace et al. 2016; Sato et al. 2016; Brandt et al. 2017). Its sister group, the Nesophontidae, was also extirpated recently (MacPhee et al. 1999). A similar pattern is observed across other terrestrial vertebrates, some with a long evolutionary history in the region (e.g. sloths, primates), which then became extinct over the last several thousand to hundreds of years due to climatic and/or anthropogenic causes (e.g. MacPhee 2009; Kemp \& Hadly 2015; Cooke et al. 2017).

The LACM Loc. 8060 fossil-bearing locality provides only a glimpse into the palaeodiversity of rodents in the Greater Antilles, at least in Puerto Rico, some 29 million years ago. Such a heteroclite rodent palaeodiversity was somewhat unexpected, and it is probably far to be exhaustively documented. However, it offers new and invaluable insights into rodent palaeodiversity, and reveals how severely under-sampled palaeontologically the West Indies are, notably for deep times. Improving our knowledge of the past diversity of West Indian vertebrates is urgently needed to further our understanding of their evolutionary history, and to dedicate efforts towards their conservation.

Acknowledgements. We are indebted to Renaud Lebrun (ISE-M, Montpellier, France) for $\mu \mathrm{CT}$-scan acquisitions and treatments. We also thank the Montpellier RIO Imaging (MRI) and the LabEx CeMEB for access to the $\mu \mathrm{CT}$-scanning station EasyTom 150 / Rx Solutions (ISE-M). Many thanks to Jonathan J. M. Calede (Ohio State University, Marion, USA) for interesting discussions about geomorphs and for all the documents (including fossil photographs) he kindly shared with us. We also thank Larry J. Flynn (Peabody Museum, Cambridge, USA) and Ross D. E. MacPhee (American Museum of Natural History, New York, USA), who provided formal reviews of this manuscript that enhanced the final version. 
This research was supported by the French "Agence Nationale de la Recherche" (ANR) in the framework of the GAARAnti program (ANR-17-CE31-0009) and the LabEx CEBA (ANR10-LABX-25-01). This paper is dedicated to the memory of Gilles Merzeraud, who passed away on October $30^{\text {th }}, 2020$. As a long-time colleague and friend, he has been a key figure in the GAARAnti team, particularly in the clarification of the stratigraphical context of the San Sebastian Formation, cropping out in the Río Guatemala at San Sebastián, Puerto Rico. This is ISE-M publication 2021-006 Sud.

Author contributions. P-OA, LM, JV-J and PM designed research; LM, JV-J, LWVL, P-HF, FP, HS-M, EJC, AMGP, JP, KIV-R, GM†, MP, PM and P-OA performed fieldwork; LM, JVJ, LWVL, P-HF, FP, EJC, AMGP, JP, KIV-R and P-OA collected palaeontological field data; LM analysed and interpreted the fossil material, and wrote the paper; P-OA produced the palaeobiogeographical map; P-OA, JV-J, LWVL, P-HF, FP, J-JC and PM critically revised and supplemented the manuscript and its illustrations.

\section{DATA ARCHIVING STATEMENT}

This published work and the nomenclatural acts it contains, have been registered in ZooBank: http://zoobank.org/References/8C2E090D-E1EC-4269-9497-E2888B26F279. The raw files for the $\mu \mathrm{CT}$-scan data and renderings of the $3 \mathrm{D}$ digital models of the fossil dental specimens described in this article are available on the online open-access platform MorphoMuseuM: https://doi.org/10.18563/journal.m3.128.

\section{REFERENCES}

ALI, J. R. 2012. Colonizing the Caribbean: is the GAARlandia land-bridge hypothesis gaining a foothold? Journal of Biogeography, 39, 431-433. 
ALONSO, R., CRAWFORD, A. J. and BERMINGHAM, E. 2012. Molecular phylogeny of an endemic radiation of Cuban toads (Bufonidae: Peltophryne) based on mitochondrial and nuclear genes. Journal of Biogeography, 39, 434-451.

ASHER, R. J., MCKENNA, M. C., EMRY, R. J., TABRUM, A. R. and KRON, D. G. 2002. Morphology and relationships of Apternodus and other extinct, zalambdodont, placental mammals. Bulletin of the American Museum of Natural History, 273, 1-117.

BERG, D. E. 1969. Charactosuchus kugleri, eine neue Krokodilart aus dem Eozän von Jamaica. Eclogae Geologicae Helvetiae, 62, 731-735.

BLACKBURN, D. C., KEEFE, R. M., VALLEJO-PAREJA, M. C. and VÉLEZ-JUARBE, J. 2020. The earliest record of Caribbean frogs: a fossil coquí from Puerto Rico. Biological Letters, 16, 20190947.

BONAPARTE, C. L. 1845. Catalogo Metodico dei Mammiferi Europei. Coi Tipi di Luigi di Giacomo Pirola, Milano, 32 pp.

BOSCHMAN, L. M., VAN HINSBERGEN, D. J. J., TORSVIK, T. H., SPAKMAN, W. and PINDELL, J. L. 2014. Kinematic reconstruction of the Caribbean region since the Early Jurassic. Earth-Science Reviews, 138, 102-136.

BOWDICH, T. E. 1821. An Analysis of the Natural Classifications of Mammalia for the Use of Students and Travellers. Paris.

BRACE, S., THOMAS, J. A., DALÉN, L., BURGER, J., MACPHEE, R. D. E., BARNES, I. and TURVEY, S. T. 2016. Evolutionary history of the Nesophontidae, the last unplaced recent mammal family. Molecular Biology and Evolution, 33, 3095-3103.

— TURVEY, S. T., WEKSLER, M., HOOGLAND, M. L. P. and BARNES, I. 2015. Unexpected evolutionary diversity in a recently extinct Caribbean mammal radiation. Proceedings of the Royal Society B, 282, 20142371.

BRANDT, A. L., GRIGOREV, K., AFANADOR-HERNÁNDEZ, Y. M., PAULINO, L. A., MURPHY, W. J., NÚÑEZ, A., KOMISSAROV, A., BRANDT, J. R., DOBRYNIN, P., HERNÁNDEZ-MARTICH, J. D., MARÍA, R., O'BRIEN, S. J., RODRÍGUEZ, L. E., MARTÍNEZ-CRUZADO, J. C., OLEKSYK, T. K. and ROCA, A. L. 2017. Mitogenomic sequences support a north-south subspecies subdivision within Solenodon paradoxus. Mitochondrial DNA Part A, 28, 662-670.

BURKE, J. J. 1934. New Duchesne River rodents and a preliminary survey of the Adjidaumidae. Annals of the Carnegie Museum, 23, 391-398.

BUSKIRK, R. E. 1985. Zoogeographic patterns and tectonic history of Jamaica and the northern Caribbean. Journal of Biogeography, 12, 445-461. 
CALEDE, J. J. M. and GLUSMAN, J. W. 2017. Geometric morphometric analyses of worn cheek teeth help identify extant and extinct gophers (Rodentia, Geomyidae). Palaeontology, 60, 281-307.

- and RASMUSSEN, D. L. 2020. New gophers (Rodentia: Geomyidae) from the Cabbage Patch Beds of Montana (Renova Formation) and the phylogenetic relationships within Entoptychinae. Annals of Carnegie Museum, 86, 107-167.

ČANDEK, K., AGNARSSON, I., BINFORD, G. J. and KUNTNER, M. 2019. Biogeography of the Caribbean Cyrtognatha spiders. Scientific Reports, 9, 397.

CHAMBERLAND, L., MCHUGH, A., KECHEJIAN, S., BINFORD, G. J., BOND, J. E., CODDINGTON, J., DOLMAN, G., HAMILTON, C. A., HARVEY, M. S., KUNTNER, M. and AGNARSSON, I. 2018. From Gondwana to GAARlandia: evolutionary history and biogeography of ogre-faced spiders (Deinopis). Journal of Biogeography, 45, 24422457.

COOKE, S. B., DÁVAlOS, L. M., MYCHAJLIW, A. M., TURVEY, S. T. and UPHAM, N. S. 2017. Anthropogenic extinction dominates Holocene declines of West Indian mammals. Annual Review of Ecology, Evolution, and Systematics, 48, 301-327.

COOPER, R. G. 2008. A synopsis of rodent species in the Caribbean Islands, endemic and invasive. Living World - Journal of the Trinidad and Tobago Field Naturalists'Club, 1-7.

COPE, E. D. 1873. Synopsis of new Vertebrata from the Tertiary of Colorado, obtained during the summer of 1873. Government Printing Office, Washington, D.C.

COPE, E. D. 1878. Description of new extinct Vertebrata from the upper Tertiary and Dakota formations. Bulletin of the United States Geological and Geographical Survey, 4, 379-396.

CORNÉE, J.-J., BOUDAGHER-FADEL, M., PHILIPPON, M., LÉTICÉE, J.-L., LEGENDRE, L., MAINCENT, G., LEBRUN, J.-F. and MÜNCH, P. 2020. Paleogene carbonate systems of Saint Barthélemy, Lesser Antilles: stratigraphy and general organization. Newsletters on Stratigraphy, 53, 461-478.

CORNÉE, J.-J., MÜNCH, P., PHILIPPON, M., BOUDAGHER-FADEL, M., QUILLEVÉRÉ, F., MELINTE-DOBRINESCU, M., LEBRUN, J.-F., GAY, A., MEYER, S., MONTHEIL, L., LALLEMAND, S., MARCAILlOU, B., LAURENCIN, M., LEGENDRE, L., GARROCQ, C., BOUCARD, M., BESLIER, M.-O., LAIGLE, L., SCHENINI, L., FABRE, P.-H., ANTOINE, P.-O. and MARIVAUX, L. with the GARANTI and ANTITHESIS Scientific Parties. 2021. Lost islands in the northern Lesser Antilles: possible milestones in the Cenozoic dispersal of terrestrial organisms between South-America and the Greater Antilles. Earth-Science Reviews, 217, 103617. 
COURCELLE, M., TILAK, M.-K., LEITE, Y. L. R., DOUZERY, E. J. P. and FABRE, P.-H. 2019. Digging for the spiny rat and hutia phylogeny using a gene capture approach, with the description of a new mammal subfamily. Molecular Phylogenetics and Evolution, 136, $241-253$.

CREWS, S. C. and ESPOSITO, L. A. 2020. Towards a synthesis of the Caribbean biogeography of terrestrial arthropods. BMC Evolutionary Biology, 20, 12.

DÁVALOS, L. M. 2004. Phylogeny and biogeography of Caribbean mammals. Biological Journal of the Linnean Society, 81, 373-394.

DELSUC, F., KUCH, M., GIBB, G. C., KARPINSKI, E., HACKENBERGER, D., SZPAK, P., MARTÍNEZ, J. G., MEAD, J. I., MCDONALD, H. G., MACPHEE, R. D. E., BILLET, G., HAUTIER, L. and POINAR, H. N. 2019. Ancient mitogenomes reveal the evolutionary history and biogeography of sloths. Current Biology, 29, 2031-2042.

DOMNING, D. P. 2001a. The earliest known fully quadrupedal sirenian. Nature, 413, 625627.

DOMNING, D. P. 2001b. Sirenians, seagrasses, and Cenozoic ecological change in the Caribbean. Palaeogeography, Palaeoclimatology, Palaeoecology, 166, 27-50.

— and CLARK, J. M. 1993. Jamaican Tertiary marine Vertebrata. 413-416. In WRIGHT, R. M. and ROBINSON, E. (eds). Biostratigraphy of Jamaica. The Geological Society of America, Inc., Boulder.

— EMRY, R. J., PORTElL, R. W., DONOVAN, S. K. and SCHINDLER, K. S. 1997. Oldest West Indian land mammal: rhinocerotoid ungulate from the Eocene of Jamaica. Journal of Vertebrate Paleontology, 17, 638-641.

DZIKI, A., BINFORD, G. J., GODDINGTON, J. A. and AGNARSSON, I. 2015. Spintharus flavidus in the Caribbean - a 30 million year biogeographical history and radiation of a 'widespread species'. PeerJ, 3, e1422.

FABRE, P.-H., UPHAM, N. S., EMMONS, L. H., JUSTY, F., LEITE, Y. L. R., LOSS, A. C., ORLANDO, L., TILAK, M.-K., PATTERSON, B. D. and DOUZERY, E. J. P. 2017. Mitogenomic phylogeny, diversification, and biogeography of South American spiny rats. Molecular Biology and Evolution, 34, 613-633.

— VILSTRUP, J. T., RAGHAVAN, M., DER SARKISSIAN, C., WILLERSLEV, E., DOUZERY, E. J. P. and ORLANDO, L. 2014. Rodents of the Caribbean: origin and diversification of hutias unravelled by next-generation museomics. Biological Letters, 10 , 20140266. 
FAHLBUSCH, V. 1968. Neue Eomyidae (Rodentia, Mam.) aus einer aquitanen Spaltenfüllung von Weißenburg in Bayern. Mitteilungen der Bayerischen Staatssammlung für Paläontologie und Historische Geologie, 8, 219-245.

FLYNN, L. J. 2008. 25. Eomyidae. 415-427. In JANIS, C. M., GUNNELL, G. F. and UHEN, M. D. (eds). Evolution of Tertiary Mammals of North America. Cambridge University Press, Cambridge.

— and JACOBS, L. L. 2008. 23. Castoroidea. 391-405. In JANIS, C. M., GUNNELL, G. F. and UHEN, M. D. (eds). Evolution of Tertiary Mammals of North America. Cambridge University Press, Cambridge.

— LINDSAY, E. H. and MARTIN, R. A. 2008. 26. Geomorpha. 428-455. In JANIS, C. M., GUNNELL, G. F. and UHEN, M. D. (eds). Evolution of Tertiary Mammals of North America. Cambridge University Press, Cambridge.

FRIES, C., HIBBARD, C. W. and DUNKLE, D. H. 1955. Early Cenozoic vertebrates in the red conglomerate at Guanajuato, Mexico. Smithsonian Miscellaneous Collections, 123, 125 .

GAWNE, C. E. 1975. Rodents from the Zia Sand Miocene of New Mexico. American Museum Novitates, 2586, 1-25.

GRAHAM, A. 2003. Geohistory models and Cenozoic paleoenvironments of the Caribbean region. Systematic Botany, 28, 378-386.

HAFNER, J. C. 1993. Macroevolutionary diversification in heteromyid rodents: heterochrony and adaptation in phylogeny. 291-318. In GENOWAYS, H. H. and BROWN, J. H. (eds). Biology of the Heteromyidae. The American Society of Mammalogists.

— LIGHT, J. E., HAFNER, D. J., HAFNER, M. S., REDDINGTON, E., ROGERS, D. S. and RIDDLE, B. R. 2007. Basal clades and molecular systematics of heteromyid rodents. Journal of Mammalogy, 88, 1129-1145.

HARRIS, J. M. and WOOD, A. E. 1969. A new genus of eomyid rodent from the Oligocene Ash Spring local fauna of Trans-Pecos Texas. The Pearce-Sellards Series Texas Memorial Museum, 14, 1-7.

HAY, O. P. 1899. Notes on the nomenclature of some North American fossil vertebrates. Science, 10, 253-254.

HEDGES, S. B. 1996. Historical biogeography of West Indian vertebrates. Annual Review of Ecology and Systematics, 27, 163-196. 
HEDGES, S. B. 2001. Caribbean biogeography: an outline. 15-33. In WOODS, C. A. and SERGILE, F. E. (eds). Biogeography of the West Indies: Patterns and Perspectives. CRC Press, Boca Raton.

— 2006. Paleogeography of the Antilles and origin of West Indian terrestrial vertebrates. Annals of the Missouri Botanical Garden, 93, 231-244.

— HASS, C. A. and MAXSON, L. R. 1992. Caribbean biogeography: molecular evidence for dispersal in West Indian terrestrial vertebrates. Proceedings of the National Academy of Sciences USA, 89, 1909-1913.

HEINICKE, M. P., DUELLMAN, W. E. and HEDGES, S. B. 2007. Major Caribbean and Central American frog faunas originated by ancient oceanic dispersal. Proceedings of the National Academy of Sciences USA, 104, 10092-10097.

ITURRALDE-VINENT, M. A. 2006. Meso-Cenozoic Caribbean paleogeography: implications for the historical biogeography of the region. International Geology Review, 48, 791-827.

— and MACPHEE, R. D. E. 1996. Age and paleogeographical origin of Dominican amber. Science, 273, 1850-1852.

— 1999. Paleogeography of the Caribbean region: implications for Cenozoic biogeography. Bulletin of the American Museum of Natural History, 238, 1-95.

JIMÉNEZ-HIDALGO, E., GUERRERO-ARENAS, R. and SMITH, K. T. 2018. Gregorymys veloxikua, the oldest pocket gopher (Rodentia: Geomyidae), and the early diversification of Geomyoidea. Journal of Mammalian Evolution, 25, 427-439.

— SMITH, K. T., GUERRERO-ARENAS, R. and ALVARADO-ORTEGA, J. 2015. The first Late Eocene continental faunal assemblage from tropical North America. Journal of South American Earth Sciences, 57, 39-48.

KELLY, T. S. 2009. A new species of Heliscomys (Rodentia, Heliscomyidae) from the Duchesnean (middle Eocene) Simi Valley Landfill local fauna, Sespe Formation, California. Paludicola, 7, 67-77.

KEMP, M. E. and HADLY, E. A. 2015. Extinction biases in Quaternary Caribbean lizards. Global Ecology and Biogeography, 24, 1281-1289.

KHUDOLEY, K. M. and MEYERHOFF, A. A. 1971. Paleogeography and geological history of Greater Antilles. The Geological Society of America Memoirs, 129, 1-199.

KORTH, W. W. 1992. Fossil small mammals from the Harrison Formation (late Arikareean: earliest Miocene), Cherry County, Nebraska. Annals of Carnegie Museum, 61, 69-131. 
— 1994. The Tertiary Record of Rodents in North America. Plenum Press, New York, London, $319 \mathrm{pp}$.

_ 2007. Mammals from the Blue Ash local fauna (late Oligocene), South Dakota. Rodentia,

Part 1: families Eutypomyidae, Eomyidae, Heliscomyidae, and Zetamys. Paludicola, 6, $31-40$.

— 2008a. Mammals from the Blue Ash local fauna (late Oligocene), South Dakota.

Rodentia, Part 2: families Florentiamyidae and Geomyidae. Paludicola, 7, 14-25.

— 2008b. Two new pocket mice (Mammalia, Rodentia, Heteromyidae) from the Miocene of

Nebraska and New Mexico and the early evolution of the subfamily Perognathinae. Geodiversitas, 30, 593-609.

— 2014. Rodents (Mammalia) from the Whitneyan (Middle Oligocene) Cedar Pass fauna of South Dakota. Annals of Carnegie Museum, 82, 373-398.

— and BRANCIFORTE, C. 2007. Geomyoid rodents (Mammalia) from the Ridgeview local fauna, early-early Arikareean (late Oligocene) of Western Nebraska. Annals of Carnegie Museum, 76, 177-201.

— and EATON, J. G. 2004. Rodents and a marsupial (Mammalia) from the Duchesnean (Eocene) Turtle Basin local fauna, Sevier Plateau, Utah. Bulletin of Carnegie Museum of Natural History, 36, 109-119.

— and REYNOLDS, R. E. 1994. A hypsodont gopher (Rodentia, Geomyidae) from the Clarendonian (Miocene) of California. San Bernardino County Museum Association, Special Publication, 94, 91-95.

- and SAMUELS, J. X. 2015. New rodent material from the John Day Formation (Arikareean, Middle Oligocene to Early Miocene) of Oregon. Annals of Carnegie Museum, 83, 19-84.

— WAHLERT, J. H. and EMRY, R. J. 1991. A new species of Heliscomys and recognition of the family Heliscomyidae (Geomyoidea: Rodentia). Journal of Vertebrate Paleontology, 11, 247-256.

LEGENDRE, S. 1986. Analysis of mammalian communities from the Late Eocene and Oligocene of Southern France. Palaeovertebrata, 16, 191-212.

LEWIS, J. F., DRAPER, G., BOURDON, C., BOWIN, C., MATTSON, P., MAURRASSE, F., NAGLE, F. and PARDO, G. 1990. Geology and tectonic evolution of northern Caribbean margin. 77-140. In DENGO, G. and CASE, J. E. (eds). The Geology of North America, vol. H, The Caribbean region. Geological Society of America, Boulder, CO. 
LINDSAY, E. H. 1972. Small mammal fossils from the Barstow Formation, California. University of California Publications in Geological Sciences, 93, 1-104.

LINNAEUS, C. 1758. Systema naturae per regna tria naturae, secundum classes, ordines, genera, species cum characteribus, differentiis, synomymis, locis. Laurentius Salvius, Holmia, Stockholm, 824 pp.

MACPHEE, R. D. E. 2005. 'First' appearances in the Cenozoic land-mammal record of the Greater Antilles: significance and comparison with South American and Antarctic records. Journal of Biogeography, 32, 551-564.

— 2009. 9. Insulae infortunatae: establishing a chronology for Late Quaternary mammal extinctions in the West Indies. 169-193. In HAYNES, G. (ed.) American Megafaunal Extinctions at the End of the Pleistocene. Springer, Dordrecht, The Netherlands.

FLEMMING, C. and LUNDE, D. P. 1999. "Last occurrence" of the Antillean insectivoran Nesophontes: new radiometric dates and their interpretation. American Museum Novitates, 326, 1-21.

— and ITURRALDE-VINENT, M. A. 1995. Origin of the Greater Antillean land mammal fauna, 1: new Tertiary fossils from Cuba and Puerto Rico. American Museum Novitates, 3141, 1-30.

— and ITURRALDE-VINENT, M. A. 2005. The interpretation of Caribbean paleogeography: reply to Hedges. 175-184. In ALCOVER, J. A. and BOVER, P. (eds). Proceedings of the International Symposium on Insular Vertebrate Evolution: the Palaeontological Approach. Monografies de la Societat d'Historia Natural de les Balears.

— ITURRALDE-VINENT, M. A. and GAFFNEY, E. S. 2003. Domo de Zaza, an early Miocene vertebrate locality in South-Central Cuba, with notes on the tectonic evolution of Puerto Rico and the Mona Passage. American Museum Novitates, 3394, 1-42.

- SINGER, R. and DIAMOND, M. 2000. Late Cenozoic Land Mammals from Grenada, Lesser Antilles Island-Arc. American Museum Novitates, 3302, 1-20.

MANN, P. 2007. Overview of the tectonic history of northern Central America. 1-19. In MANN, P. (ed.) Geologic and Tectonic Development of the Caribbean Plate Boundary in Northern Central America. Geological Society of America Special Papers, 428.

MARIVAUX, L., VÉLEZ-JUARBE, J. and ANTOINE, P.-O. 2021. 3D models related to the publication: An unpredicted ancient colonization of the West Indies by North American rodents: dental evidence of a geomorph from the early Oligocene of Puerto Rico. MorphoMuseum. https://doi.org/10.18563/journal.m3.128 
— VÉlez-JUARBe, J., MERZERAud, G., PUJOS, F., ViÑola LÓPEZ, L. W., BOIVIN, M., SANTOS-MERCADO, H., CRUZ, E. J., GRAJALES, A., PADILlA, J., VÉLEZ-ROSADO, K. I., PHILIPPON, M., LÉTICÉE, J.-L., MÜNCH, P. and ANTOINE, P.-O. 2020. Early Oligocene chinchilloid caviomorphs from Puerto Rico and the initial rodent colonization of the West Indies. Proceedings of the Royal Society B, 287, 20192806.

— VIANEY-LIAUD, M. and JAEGER, J.-J. 2004. High-level phylogeny of early Tertiary rodents: dental evidence. Zoological Journal of the Linnean Society, 142, 105-134.

MARTIN, L. D. 1974. New rodents from the Lower Miocene Gering Formation of Western Nebraska. Occasional Papers of the Museum of Natural History. The University of Kansas, 32, $1-12$.

MATOS-MARAVÍ, P., NÚÑEZ ÁGUILA, R., PEÑA, C., MILLER, J. Y., SOURAKOV, A. and WAHLBERG, N. 2014. Causes of endemic radiation in the Caribbean: evidence from the historical biogeography and diversification of the butterfly genus Calisto (Nymphalidae: Satyrinae: Satyrini). BMC Evolutionary Biology, 14, 199.

MEREDITH, R. W., JANEČKA, J. E., GATESY, J., RYDER, O. A., FISHER, C. A., TEEling, E. C., GOODBlA, A., EIZIRIK, E., SIMÃO, T. L. L., STADLER, T., RABOSKY, D. L., HONEYCUTT, R. L., FLYNN, J. J., INGRAM, C. M., STEINER, C., WILliAMS, T. L., ROBINSON, T. J., BURK-HERRICK, A., WESTERMAN, M., AYOUB, N. A., SPRINGER, M. S. and MURPHY, W. J. 2011. Impacts of the Cretaceous terrestrial revolution and KPg extinction on mammal diversification. Science, 334, 521524.

MILLER, K. G., BROWNING, J. V., SCHMELZ, W. J., KOPP, R. E., MOUNTAIN, G. S. and WRIGHT, J. D. 2020. Cenozoic sea-level and cryospheric evolution from deep-sea geochemical and continental margin records. Science Advances, 6, eaaz1346.

MONTGElARD, C., FORTY, E., ARNAL, V. and MATTHEE, C. A. 2008. Suprafamilial relationships among Rodentia and the phylogenetic effect of removing fast-evolving nucleotides in mitochondrial, exon and intron fragments. BMC Evolutionary Biology, 8, $321-337$.

MORGAN, G. S. 1993. Quaternary land vertebrates of Jamaica. 417-442. In WRIGHT, R. M. and ROBINSON, E. (eds). Biostratigraphy of Jamaica. Geological Society of America Memoir.

ORTEGA-ARIZA, D., FRANSEEN, E. K., SANTOS-MERCADO, H., RAMÍREZMARTÍNEZ, W. R. and CORE-SUÁREZ, E. E. 2015. Strontium isotope stratigraphy for 
Oligocene-Miocene carbonate systems in Puerto Rico and the Dominican Republic: implications for Caribbean processes affecting depositional history. The Journal of Geology, 123, 539-560.

ORTIZ-CABALLERO, E., JIMÉNEZ-HIDALGO, E. and BRAVO-CUEVAS, V. M. 2020. A new species of the gopher Gregorymys (Rodentia, Geomyidae) from the early Oligocene (Arikareean 1) of southern Mexico. Journal of Paleontology, 94, 1191-1201.

PATTON, T. H. 1969. An Oligocene land vertebrate fauna from Florida. Journal of Paleontology, 43, 543-546.

PHILIPPON, M., CORNÉE, J.-J., MÜNCH, P., VAN HINSBERGEN, D. J. J., BOUDAGHER-FADEL, M., GAILlER, L., BOSCHMAN, L. M., QUILLEVÉRÉ, F., MONTHEIL, L., GAY, A., LEBRUN, J.-F., LALLEMAND, S., MARIVAUX, L., ANTOINE, P.-O. with the GARANTI team. 2020. Eocene intra-plate shortening responsible for the rise of a faunal pathway in the northeastern Caribbean realm. PLoS One, 15, e0241000.

PINDELL, J. L. and BARRETT, S. F. 1990. Geological evolution of the Caribbean region: a plate tectonic perspective. 405-432. In DENGO, G. and CASE, J. E. (eds). The Geology of North America, vol. H, The Caribbean Region. Geological Society of America, Boulder, $\mathrm{CO}$.

- and KENNAN, L. 2009. Tectonic evolution of the Gulf of Mexico, Caribbean and northern South America in the mantle reference frame: an update. 1-55. In JAMES, K. H., LORENTE, M. A. and PINDELL, J. L. (eds). The Origin and Evolution of the Caribbean Plate. Geological Society of London, Special Publications, London, 328.

— STANEK, K., MARESCH, W. V. and DRAPER, G. 2009. Foundations of Gulf of Mexico and Caribbean evolution: eight controversies resolved. Geology Acta, 4, 303-341. POINAR, G. Jr. and WAKE, D. B. 2015. Palaeoplethodon hispaniolae gen. n., sp. n. (Amphibia: Caudata), a fossil salamander from the Caribbean. Palaeodiversity, 8, 21-29. PREGILL, G. K. 1999. Eocene lizard from Jamaica. Herpetologica, 55, 157-161.

PRESSLEE, S., SLATER, G. J., PUJOS, F., FORASIEPI, A. M., FISCHER, R., MOLLOY, K., MACKIE, M., OLSEN, J. V., KRAMARZ, A., TAGLIORETTI, M., SCAGLIA, F., LEZCANO, M., LANATA, J. L., SOUTHON, J., FERANEC, R., BLOCH, J., HAJDUK, A., MARTIN, F. M., SAlAS-GiSMONDI, R., REGUERO, M., MUIZON, C. DE, GREENWOOD, A., CHAIT, B. T., PENKMAN, K., COLLINS, M. and MACPHEE, R. D. E. 2019. Palaeoproteomics resolves sloth relationships. Nature Ecology and Evolution, 3, 1121-1130. 
RENSBERGER, J. M. 1973. Pleurolicine rodents (Geomyoidea) of the John Day Formation, Oregon. University of California Publications in Geological Sciences, 102, 1-95.

ROBINSON, E. 1994. Jamaica. 111-127. In DONOVAN, S. K. and JACKSON, T. A. (eds). Caribbean Geology: an Introduction. University of West Indies Publishers Association, Kingston.

ROCA, A. L., BAR-GAL, G. K., EIZIRIK, E., HELGEN, K. M., MARIA, R., SPRINGER, M. S., O'BRIEN, S. J. and MURPHY, W. J. 2004. Mesozoic origin for West Indian insectivores. Nature, 429, 649-651.

SATO, J. J., OHDACHI, S. D., ECHENIQUE-DIAZ, L. M., BORROTO-PÁEZ, R., BEGUÉQUILA, G., DELGADO-LABAÑINO, J. L., GÁMEZ-DÍEZ, J., ALVAREZ-LEMUS, J., TRUONG NGUYEN, S., YAMAGUCHI, N. and KITA, M. 2016. Molecular phylogenetic analysis of nuclear genes suggests a Cenozoic over-water dispersal origin for the Cuban solenodon. Scientific Reports, 6, 31173.

SCHLÖSSER, M. 1884. Die Nager des europäischen Tertiärs nebst Betrachtungen über die Organisation und die geschichtliche Entwicklung der Nager überhaupt. Palaeontographica, Abteilung A, 31, 1-143.

SLAUGHTER, B. H. 1981. A new genus of geomyoid rodent from the Miocene of Texas and Panama. Journal of Vertebrate Paleontology, 1, 111-115.

SMITH, K. S., CIFFELI, R. L. and CZAPLEWSKI, N. J. 2006. A new genus of eomyid rodent from the Miocene of Nevada. Acta Palaeontologica Polonica, 51, 385-392.

SPRINGER, M. S., MURPHY, W. J. and ROCA, A. L. 2018. Appropriate fossil calibrations and tree constraints upholds the Mesozoic divergence of solenodons from other extant mammals. Molecular Phylogenetics and Evolution, 121, 158-165.

STANEK, K. P., MARESCH, W. V. and PINDELL, J. L. 2009. The geotectonic story of the northwestern branch of the Caribbean Arc: implications from structural and geochronological data of Cuba. 361-398. In JAMES, K. H., LORENTE, M. A. and PINDELL, J. L. (eds). The Origin and Evolution of the Caribbean Plate. Geological Society of London, Special Publications.

STEHLIN, H. G. and SCHAUB, S. 1951. Die trigonodontie der simplicidentaten Nager. Schweizerische Palaeontologisches Abhandlungen, 67, 1-385.

TAPALTSYAN, V., ERONEN, J. T., LAWING, A. M., SHARIR, A., JANIS, C., JERNVALL, J. and KLEIN, O. D. 2015. Continuously growing rodent molars result from a predictable quantitative evolutionary change over 50 million years. Cell Reports, 11, 673-680. 
THALER, L. 1966. Les rongeurs fossiles du Bas-Languedoc dans leurs rapports avec l'histoire des faunes et la stratigraphie du Tertiaire d'Europe. Mémoires du Muséum National d'Histoire Naturelle, Paris, 295 pp.

TONG, Y., BINFORD, G., RHEIMS, C. A., KUNTNER, M., LIU, J. and AGNARSSON, I. 2019. Huntsmen of the Caribbean: multiple tests of the GAARlandia hypothesis. Molecular Phylogenetics and Evolution, 130, 259-268.

TURVEY, S. T. and FRITZ, S. A. 2011. The ghosts of mammals past: biological and geographical patterns of global mammalian extinction across the Holocene. Philosophical Transactions of the Royal Society B, 366, 2564-2576.

TURVEY, S. T., KENNERLEY, R. J., NUÑEZ-MIÑO, J. M. and YOUNG, R. P. 2017. The Last Survivors: current status and conservation of the non-volant land mammals of the insular Caribbean. Journal of Mammalogy, 98, 918-936.

UPHAM, N. S. and BORROTO-PAÉZ, R. 2017. Molecular phylogeography of endangered Cuban hutias within the Caribbean radiation of capromyid rodents. Journal of Mammalogy, 98, 950-963.

VÉLEZ-JUARBE, J. and BROCHU, C. A. in press. Eocene crocodyliform from Seven Rivers, Jamaica: implications for Neotropical crocodyliform biogeography and the status of Charactosuchus Langston, 1965. In PORTELL, R. W. and DOMNING, D. P. (eds). The Eocene Fossil Site of Seven Rivers, Jamaica: Geology, Paleontology, and Evolutionary and Biogeographic Implications. Springer, Berlin.

— and DOMNING, D. P. 2014. Fossil Sirenia of the West Atlantic and Caribbean region: X. Priscosiren atlantica, gen. et sp. nov. Journal of Vertebrate Paleontology, 34, 951-964.

BROCHU, C. A. and SANTOS, H. 2007. A gharial from the Oligocene of Puerto Rico: transoceanic dispersal in the history of a non-marine reptile. Proceedings of the Royal Society B, 274, 1245-1254.

— MARTIN, T., MACPHEE, R. D. E. and ORTEGA-ARIZA, D. 2014. The earliest Caribbean rodents: Oligocene caviomorphs from Puerto Rico. Journal of Vertebrate Paleontology, 34, 157-163.

WAHLERT, J. H. 1976. Jimomys labaughi, a new geomyoid rodent from the early Barstovian of North America. American Museum Novitates, 2591, 1-6.

— 1983. Relationships of the Florentiamyidae (Rodentia, Geomyoidea) based on cranial and dental morphology. American Museum Novitates, 2769, 1-23.

— 1984. Kirkomys, a new florentiamyid (Rodentia, Geomyoidea) from the Whitneyan of Sioux County, Nebraska. American Museum Novitates, 2793, 1-8. 
— 1985. Skull morphology and relationships of geomyoid rodents. American Museum Novitates, 2812, 1-20.

— 1991. The Harrymyinae, a new heteromyid subfamily (Rodentia, Geomorpha), based on cranial and dental morphology of Harrymys Munthe, 1988. American Museum Novitates, 3013, 1-23.

WALTON, A. H. and PORTER, R. M. 2008. 19. Sciuravidae. 326-335. In JANIS, C. M., GUNNELL, G. F. and UHEN, M. D. (eds). Evolution of Tertiary Mammals of North America. Cambridge University Press, Cambridge.

WILSON, D. E. and REEDER, D. M. 2005. Mammal Species of the World: a Taxonomic and Geographic Reference. Johns Hopkins University Press, Baltimore, 2142 pp.

WILSON, R. W. 1940. Two Eocene rodents from California. Carnegie Institute of Washington Publication, 514, 85-95.

— 1949. Early Tertiary rodents of North America. Carnegie Institute of Washington Publication, 584, 67-164.

WOOD, A. E. 1932. New heteromyid rodents from the Miocene of Florida. Florida State Geological Survey Bulletin, 10, 45-51.

- 1935. Evolution and relationships of the heteromyid rodents with new forms from the Tertiary of western North America. Annals of Carnegie Museum, 24, 73-262.

— 1936. Geomyoid rodents from the middle Tertiary. American Museum Novitates, 866, 131.

— 1955. Rodents from the Lower Oligocene Yoder Formation of Wyoming. Journal of Paleontology, 29, 519-524.

WOODS, C. A., BORROTO PAÉZ, R. and KILPATRICK, C. W. 2001. 18. Insular patterns and radiations of West Indian rodents. 335-353. In WOODS, C. A. and SERGILE, F. E. (eds). Biogeography of the West Indies: Patterns and Perspectives. CRC Press, Boca Raton.

YOUNG, A., FLAMENT, N., MALONEY, K., WILLIAMS, S., MATTHEWS, K., ZAHIROVIC, S. and MÜLLER, R. D. 2019. Global kinematics of tectonic plates and subduction zones since the late Paleozoic Era. Geoscience Frontiers, 10, 989-1013. 


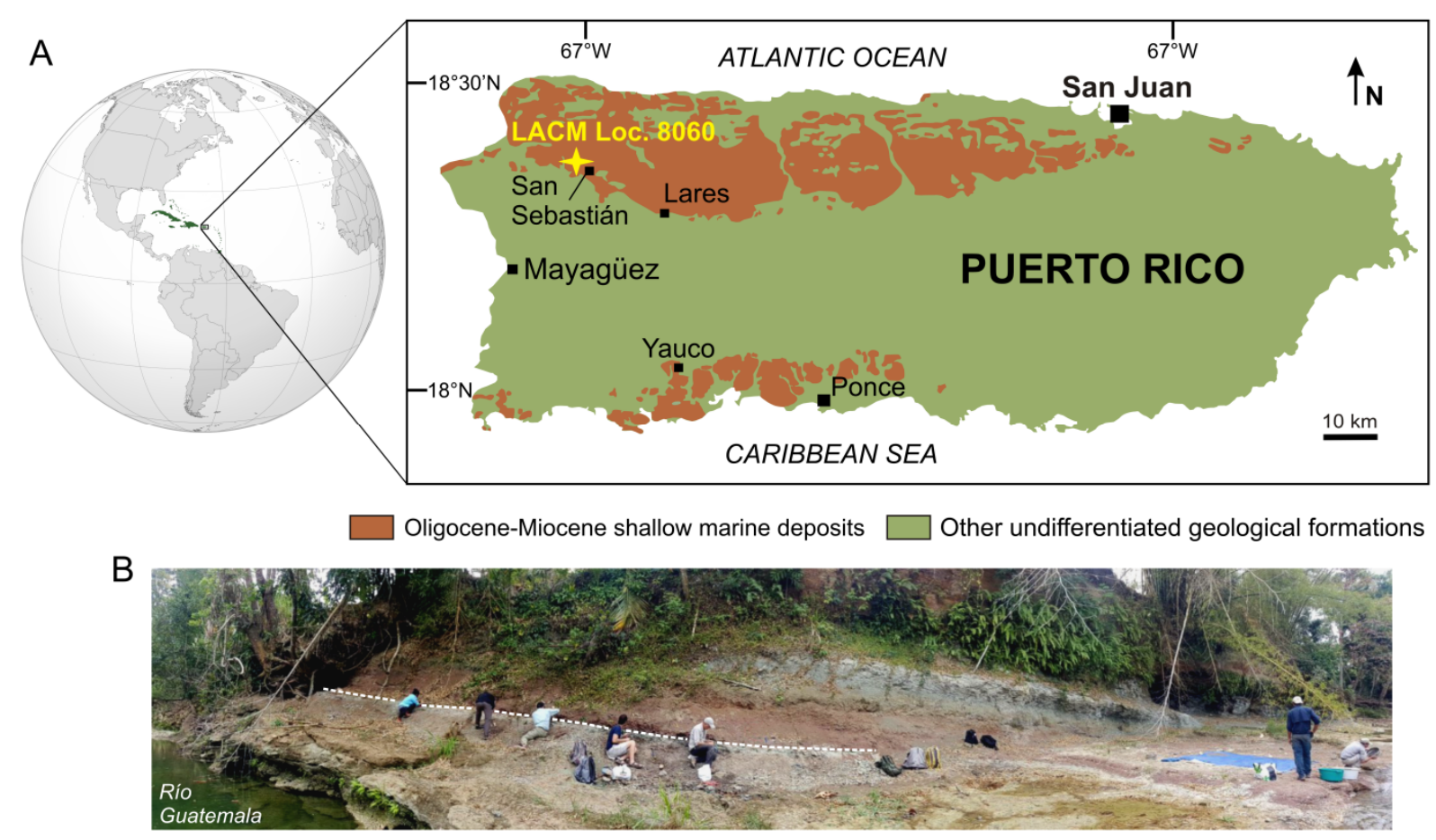

FIG 1. Location and geological maps of the LACM Loc. 8060 fossil-bearing locality. A, the locality (yellow star) is located in the Río Guatemala, which flows through the township of San Sebastián, Puerto Rico (West Indies). LACM Loc. 8060 occurs in shallow marine deposits corresponding to the lower part of the San Sebastian Formation, which outcrops along the banks of the Río Guatemala (Vélez-Juarbe et al. 2007, 2014; Marivaux et al. 2020). ${ }^{87} \mathrm{Sr} /{ }^{86} \mathrm{Sr}$ mean ages-dates calculated on low-Mg calcite shells of Kuphus incrassatus bivalves allowed for bracketing the age of the LACM Loc. 8060 between 29.78 and 29.17 Ma (late Rupelian) (Ortega-Ariza et al. 2015). B, panoramic view of LACM Loc. 8060, showing our team excavating the $15-20 \mathrm{~cm}$ thick layer of grey silty claystone (white dotted line) that yielded the fossil remains of mammals (photograph by J. Vélez-Juarbe). 


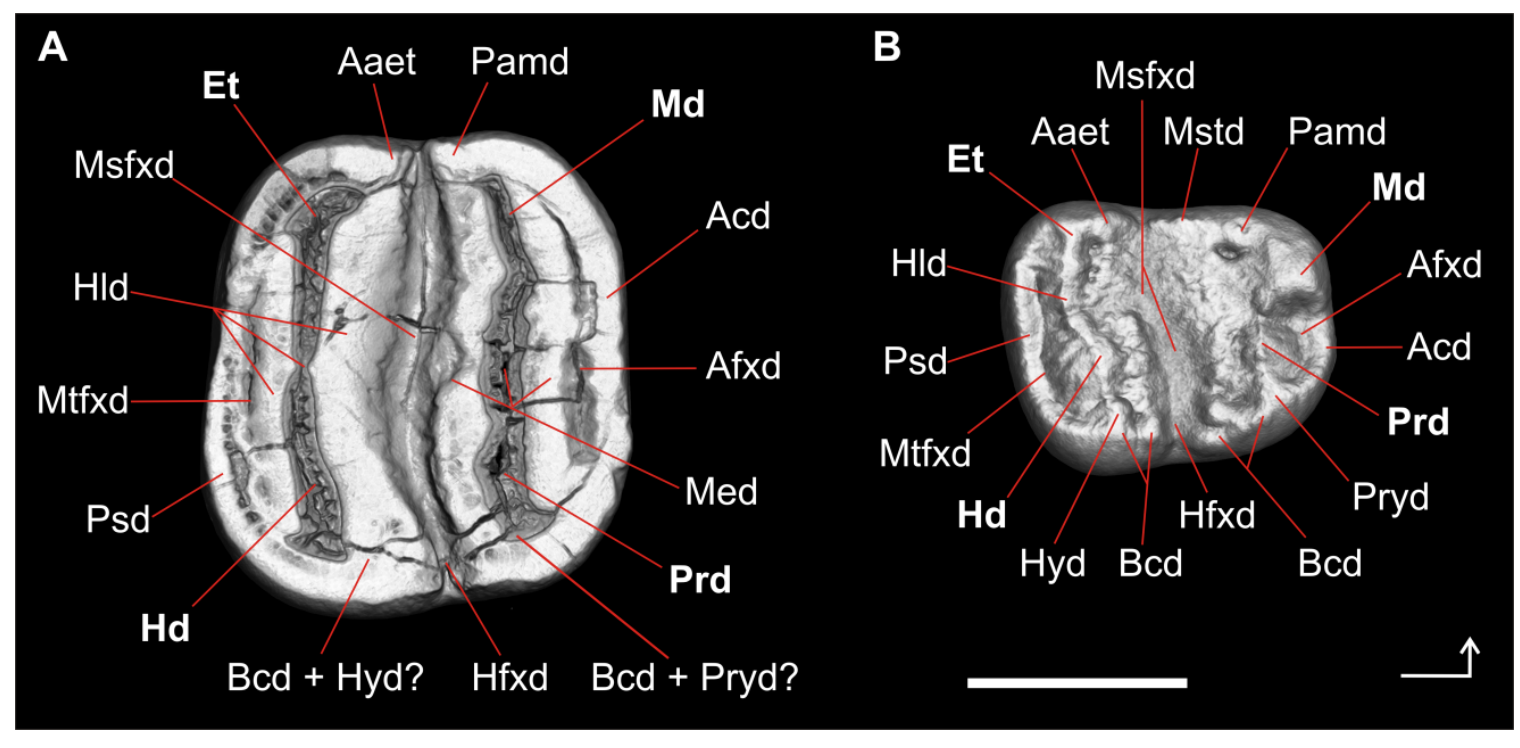

FIG 2. Dental terminology (updated and modified after Wahlert 1983; Korth 1994, 2007; Marivaux et al. 2004; Calede \& Glusman 2017; Calede \& Rasmussen 2020). The terminology is applied on the two fossil teeth from LACM Loc. 8060: A, LACM 162449, right lower molar (m1 or m2); B, LACM 162478, right fourth lower deciduous premolar (dp4). Abbreviations: Aaet, anterior arm of the entoconid; Acd, anterocingulid (or anterolophid); Afxd, anteroflexid or paraflexid (here anterofossettid); Bcd, buccal cingulid; Et, entoconid (or entoconid region); Hd, hypoconid (or hypoconid region on the molar); Hfxd, hypoflexid; Hld, hypolophid (= the main distal lophid resulting from the coalescence of the bulbous entoconid with the bulbous hypoconid + the hypostylid); Hyd, hypostylid; Md, metaconid (or metaconid region on the molar); Med, metalophid (= main mesial lophid resulting from the coalescence of the bulbous metaconid with the bulbous protoconid + the protostylid on the molar); Msfxd, mesoflexid; Mstd, mesostylid; Mtfxd, metaflexid (here metafossettid); Pamd, posterior arm of the metaconid; Prd, protoconid (or protoconid region on the molar); Pryd, protostylid; Psd, posterocingulid (or posterolophid). The white arrow indicates the orientation of the teeth on the jaw (mesiolingual). The images of the teeth are renderings of $3 \mathrm{D}$ digital models of the fossil specimen, obtained by X-ray $\mu \mathrm{CT}$ surface reconstruction. Scale bar represents $1 \mathrm{~mm}$. 


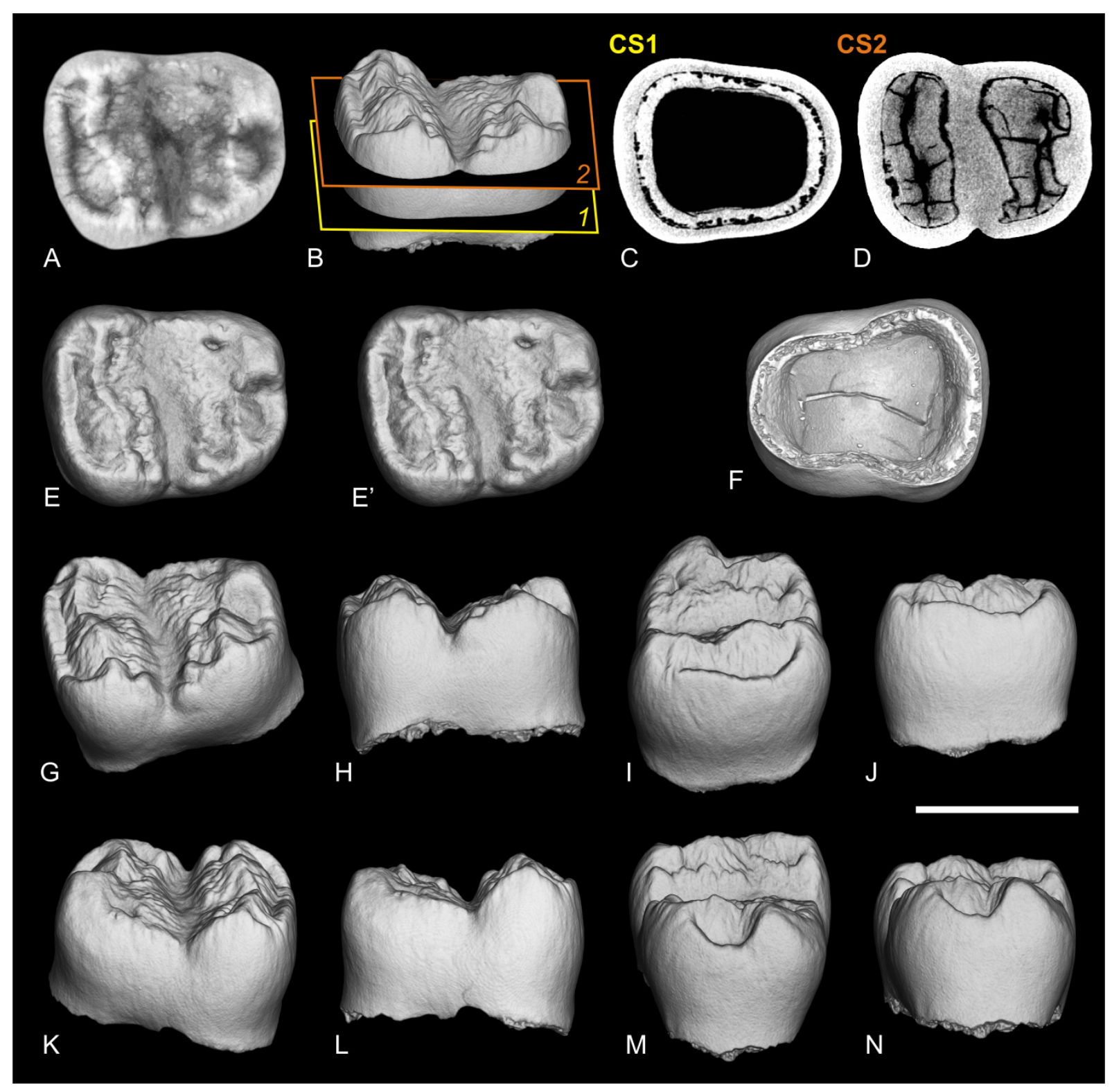

FIG 3. Caribeomys merzeraudi gen. et sp. nov. from the late early Oligocene of Puerto Rico (LACM Loc. 8060). A-N, LACM 162478, right fourth lower deciduous premolar (dp4) in occlusal (A and E-E' stereo pair), ventral (F), lingual (B, G-H), distal (I-J), buccal (K-L) and mesial $(\mathrm{M}-\mathrm{N})$ views. Sagittal cross-sections $(\mathrm{CS})$ were performed $(\mathrm{B})$ for visualizing enamel thickness at different crown heights. CS1 was made near the cervix (C) and CS2 near the occlusal surface (D). The occlusal view in A (whitened using magnesium smoke) is the result of the fusion of multi-focus images. The images in B and E-N are renderings of 3D digital models of the fossil specimen, obtained by X-ray $\mu \mathrm{CT}$ surface reconstruction. The images in $\mathrm{C}$ and $\mathrm{D}$ are 2D orthoslices of the specimen. Scale bar represents $1 \mathrm{~mm}$. 


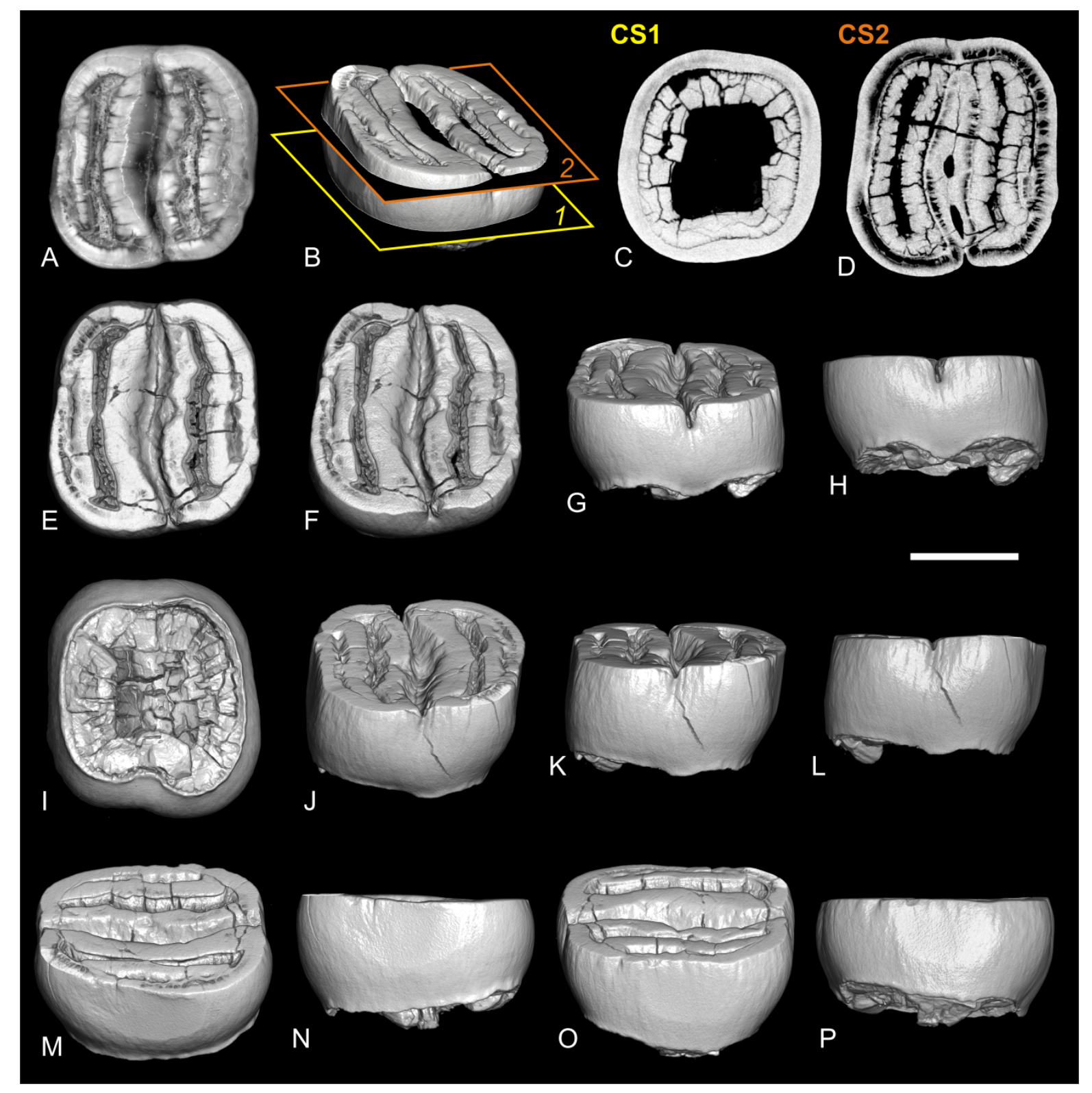

FIG 4. Caribeomys merzeraudi gen. et sp. nov. from the late early Oligocene of Puerto Rico (LACM Loc. 8060). A-P, LACM 162449, right lower molar ( $\mathrm{m} 1$ or m2) in occlusal (A, E-F), lingual $(\mathrm{B}, \mathrm{G}-\mathrm{H})$, ventral $(\mathrm{I})$, buccal $(\mathrm{J}-\mathrm{L})$, mesial $(\mathrm{M}-\mathrm{N})$ and distal $(\mathrm{O}-\mathrm{P})$ views. Sagittal cross-sections (CS) were performed (B) for visualizing the enamel thickness at different crown heights. CS1 was made near the cervix (C) and CS2 near the occlusal surface (D). The occlusal view in $\mathrm{A}$ is the result of the fusion of multi-focus images. The images in $\mathrm{B}$ and $\mathrm{E}-\mathrm{P}$ are renderings of $3 \mathrm{D}$ digital models of the fossil specimen, obtained by X-ray $\mu \mathrm{CT}$ surface reconstruction. The images in $\mathrm{C}$ and $\mathrm{D}$ are $2 \mathrm{D}$ orthoslices of the specimen. Scale bar represents $1 \mathrm{~mm}$. 


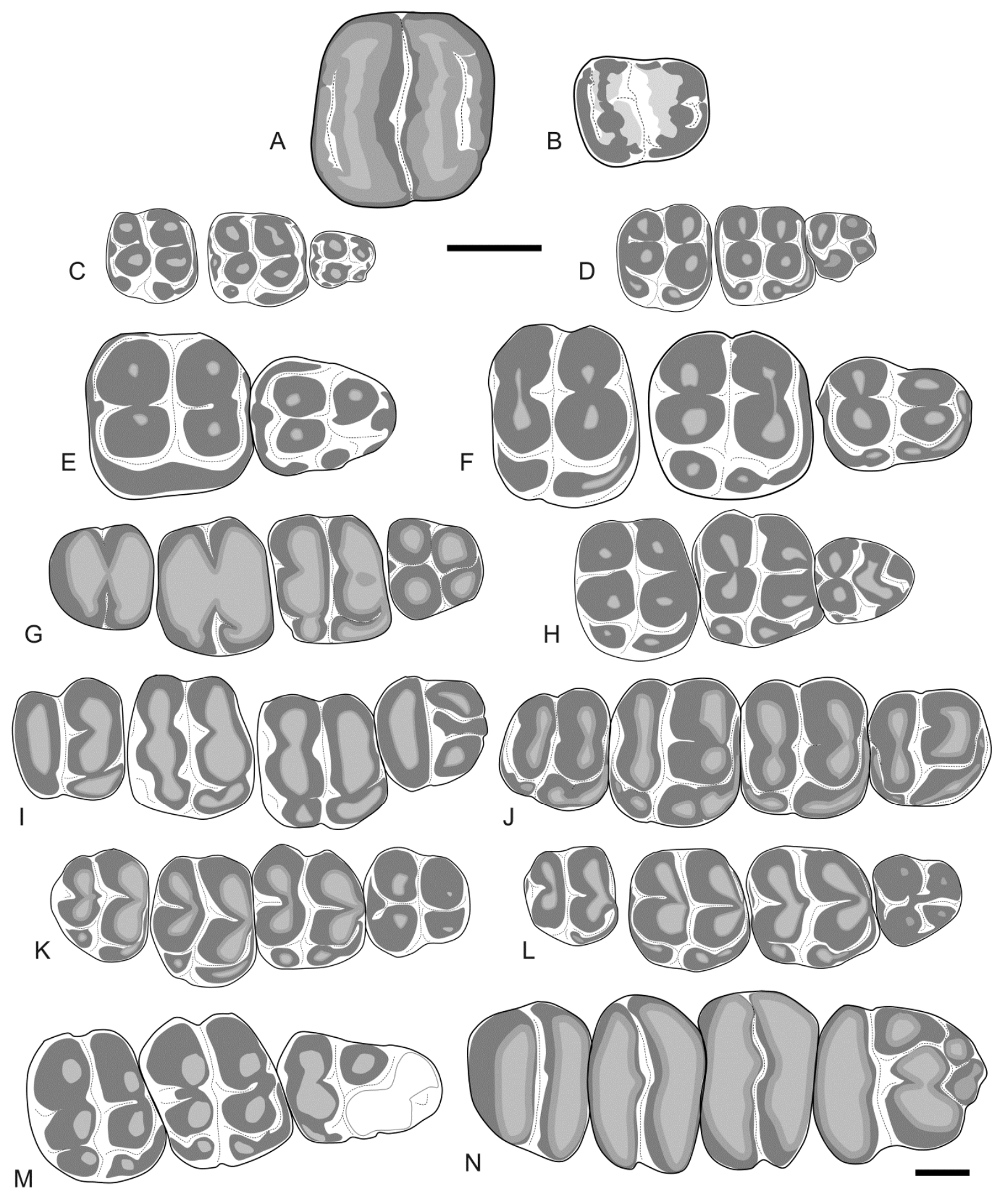

FIG 5. Lower dentition of some early geomyin geomorphs for comparisons with lower teeth of Caribeomys merzeraudi gen. et sp. nov. from the early Oligocene of Puerto Rico. A, LACM 162449, right $\mathrm{m} 1$ or $\mathrm{m} 2$ of $C$. merzeraudi; B, LACM 162478, right dp4 of $C$. merzeraudi; C, UNSM 425737, right dp4-m3 (here dp4-m2) of Heliscomys ootranderi from the early Oligocene of Wyoming, USA (Korth et al. 1991, fig. 4E); D, UNSM 130501, right p4-m2 of Heliscomys sp. from the late Oligocene of Nebraska, USA (Korth \& Branciforte 2007, fig. 2D); E, UMPE 0116, left dp4-m1 (reversed) of a geomyoid indet. from the late Eocene of Oaxaca, Mexico (Jiménez-Hidalgo et al. 2015, fig. 4B); F, UNSM 24099, 24102 and 24102 , left dp4 (reversed) and right $\mathrm{m} 1$ or $\mathrm{m} 2$ of Sanctimus cf. S. stuartae from the early 
Miocene of Nebraska, USA (Korth 1992, fig. 14I, K-L); G, MCZ 5051, left p4-m3 (reversed) of Kirkomys nebraskensis from the late Oligocene of Nebraska, USA (Korth \& Branciforte 2007, fig. 4B); H, SDSM 57391, left dp4-m2 (reversed) of Kirkomys martintau from the middle Oligocene of South Dakota, USA (Korth, 2014, fig. 9D); I, UNSM 24103, left p4-m3 (reversed) of Hitonkala macdonaldtau from the early Miocene of Nebraska, USA (Korth 1992, fig. 13C); J, Amherst 27-126, right p4-m3 of Florentiamys loomisi from the early Miocene of Wyoming, USA (Wood 1936, fig. 1-5; Stehlin \& Schaub 1951, fig. 526); K, UNSM 130000, right p4-m3 of Eochaeotodipus asulcatus from the early Miocene of Nebraska, USA (Korth 2008b, fig. 2B); L, UNSM 130217, left p4-m3 (reversed) of Proharrymys wahlerti from the late Oligocene of Nebraska, USA (Korth \& Branciforte 2007, fig. 6C); M, F:AM 51309, left dp4-m2 (reversed) of Pleurolicus cf. sulcifrons from the latest Oligocene of New Mexico, USA (Gawne 1975, fig. 9A); N, UMPE 622, right p4-m3 of Gregorymys veloxikua from the late Eocene of Oaxaca, Mexico (Jiménez-Hidalgo et al. 2018, fig. 7d). Scale bars represent $1 \mathrm{~mm}$. The scale bar at the top centre of the figure is for A-M. The scale bar at the bottom right of the figure is only for $\mathrm{N}$. 


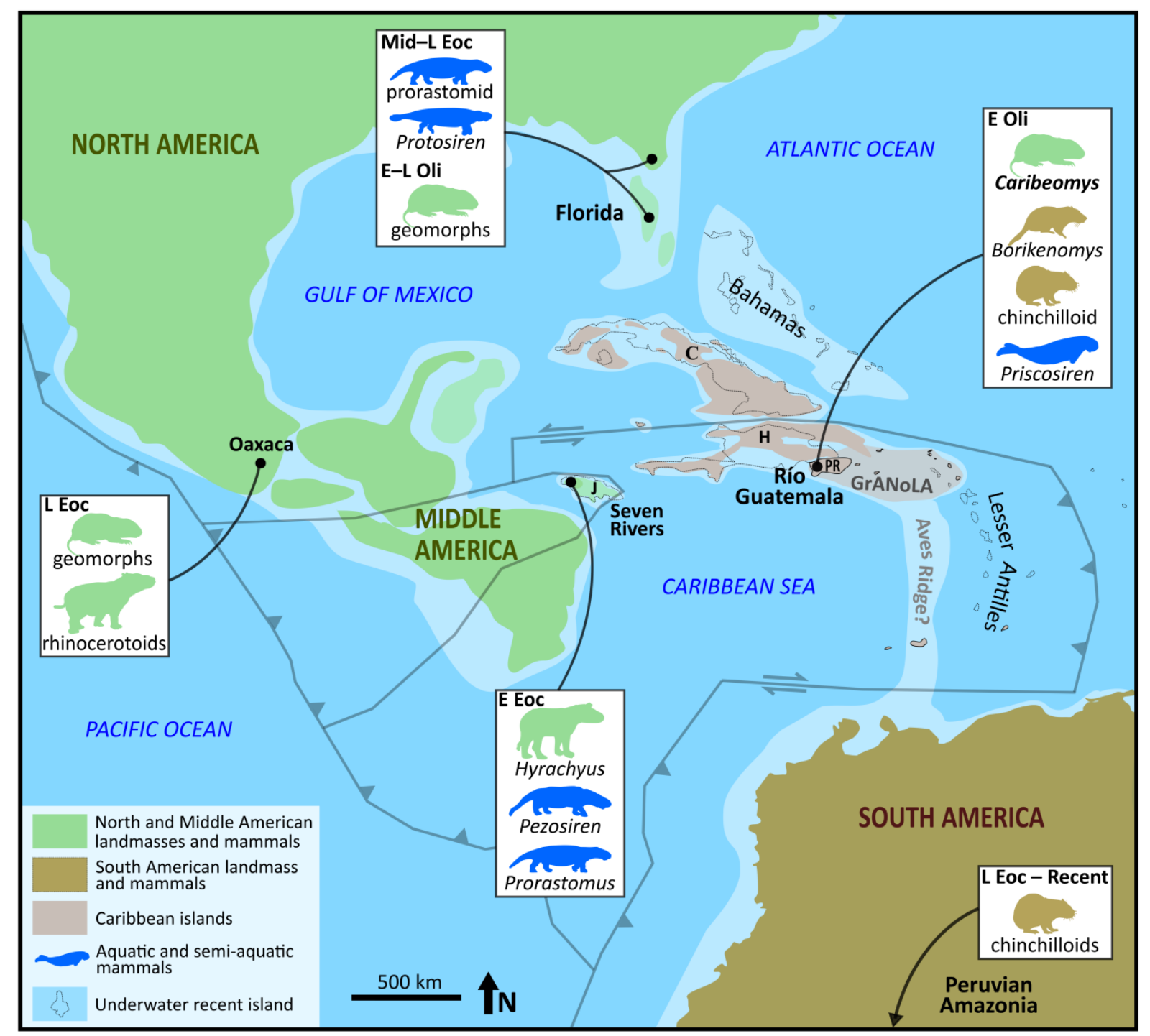

FIG 6. Palaeogeographical map of the Caribbean region by the Eocene-Oligocene Transition (34 Ma) and mammalian assemblages of interest (Eocene-Oligocene). Light landmass colours stand for areas submerged under shallow water. C, Cuba; E, early; Eoc, Eocene; GrANoLA, Greater Antilles-Northern Lesser Antilles landmass; H, Hispaniola; J, Jamaica; L, late; Mid, middle; Oli, Oligocene; PR, Puerto Rico. This original figure is based on data from Patton (1969), Domning (2001a, b), Iturralde-Vinent (2006), Jiménez-Hidalgo et al. (2018), Young et al. (2019), Cornée et al. (2020, 2021), Marivaux et al. (2020), and Philippon et al. (2020), and deeptimemaps.com. 